\title{
Bridging the Legitimacy Divide: The International Criminal Court's Domestic Perception Challenge
}

\author{
BY YVONNE M. DUTTON*
}

\begin{abstract}
International institutions like the International Criminal Court (ICC) face significant hurdles that can prevent them from establishing their legitimacy with faraway audiences. The hurdles become almost insurmountable when the ICC intervenes over the government's objection. This Article explores various factors that may influence the perceived legitimacy of international tribunals. It concludes that because the ICC faces access and communication disadvantages vis-à-vis state leaders, the ICC's road to achieving domestic perception legitimacy will be a difficult one. Without significant and pervasive in-person outreach, the ICC will probably not be able to overcome any propaganda campaign government leaders wage against it to protect themselves and their cohort from being held accountable to the victims of violence. Yet the literature identifies in-person outreach as the best way to promote a far-removed audience's awareness and understanding of an international court's operations and processes, especially because those audiences are likely socialized to distrust judicial institutions. Even with access, the ICC still must overcome cross-cultural communication barriers. State leaders,
\end{abstract}

\footnotetext{
*Associate Professor of Law, Indiana University Robert H. McKinney School of Law. The Author thanks participants at the Indiana University Maurer School of Law, the ASIL Midwest Interest Group International Law Forum, the ASIL International Criminal Law Interest Group Annual Works-in-Progress Workshop, the ASIL International Organizations Interest Group Works-In-Progress Workshop, Geoff Dancy, and Stephen Chaudoin for helpful comments on earlier drafts. The Author acknowledges funding support for this project from The Hague Institute for Global Justice and from the IUPUI Office of the Vice Chancellor for Research (Developing Diverse Researchers with InVestigative Expertise Grant) to support travel to conduct interviews in Kenya and The Hague.
} 
by contrast, share in-group status with their citizenry. A case study of Kenya, using both documentary and interview evidence, illustrates the ICC's domestic perception legitimacy challenge. After the ICC brought charges against them for committing crimes against humanity, Kenyan leaders fought back, besieging the public with rhetoric that painted the ICC as biased against Africa and a tool of colonialism. Enough Kenyans were apparently persuaded by the rhetoric that they backed leaders charged by the ICC with serious international crimes instead of supporting the ICC's efforts to provide iustice for Kenya's victims. To avoid such a situation in the future, states and other stakeholders need to help spread and advance the ICC's embodied norms of iustice and accountability so that those norms are internalized by domestic audiences. This path to achieving domestic perception legitimacy will take time, but the payoff is that the ICC might be able to fulfill its goals.

INTRODUCTION

I. The ICC AND ITS DOMESTIC PERCEPTION LEGITIMACY ............79

A. Background on the ICC …………….............................79

B. The Need for Domestic Perception Legitimacy ................84

II. The Factors Influencing Domestic Perception

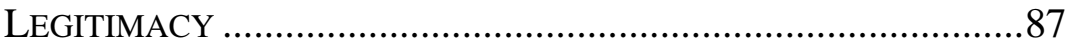

A. Proximity of the Court to the Populace .............................88

B. Quantity and Quality of the Court's Outreach..................90

C. The Populace's Other Opportunities for Awareness and Understanding

D. The Degree to Which the Populace Trusts its Own Courts ....................................................................96

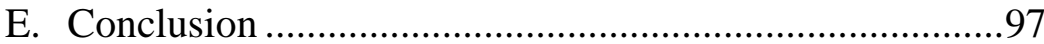

III. KenYa-As-Illustration: ICC OUtREACH AND THE DOMESTIC NARRATIVE ...........................................................97

A. Introducing the Kenya Case Study ....................................97

B. Evidence from Kenya .....................................................101

1. Raising Awareness and Understanding .....................101

a. ICC Outreach ......................................................102

b. Civil Society's Pro-ICC Outreach .......................106 
c. Hostile Leaders' Anti-ICC Narrative.................109

i. Reaching and Rallying the Domestic Audience ..................................................110

ii. Leaders' Communication Advantage at Work 113

2. Distrust of Domestic Legal Institutions...................117

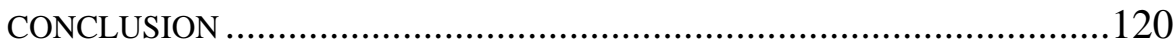




\section{INTRODUCTION}

When States voted to create the International Criminal Court (ICC) at the Rome Conference in 1998, ${ }^{1}$ the overall sentiment was one of euphoria and hope. Conference attendees applauded the Court's creation, expressing the belief that this new permanent world court would transform international criminal law and ensure that perpetrators of mass atrocities could no longer escape justice. ${ }^{2}$ The same sentiment prevailed when the Court became a reality in $2002 .^{3}$ At that time, United Nations Secretary-General Kofi Annan opined that by creating the Court, States had "dealt a decisive blow" to impunity. ${ }^{4}$ At the first meeting of the Assembly of States Parties to the ICC in 2002, William Pace of the Coalition for the International Criminal Court ${ }^{5}$ argued that the "entry into force of the new system of international criminal justice represents a truly great victory for the protection of universal human rights and the advancement of human security." 6 The treaty creating the ICC, the Rome Statute, reflects these high hopes. According to the Preamble, a primary goal of the

1. Rome Statute of the International Criminal Court, July 17, 1998, 2187 U.N.T.S. 38544 [hereinafter Rome Statute].

2. See John Washburn, The Negotiation of the Rome Statute for the International Criminal Court and International Lawmaking in the $21^{\text {st }}$ Century, 11 PACE INT'L L. REV. 361, 361-362 (1999) (stating that upon the favorable vote for the Rome Statute, diplomats abandoned themselves to a celebration in recognition of the future transformation of the application and enforcement of international criminal law). Not all States or commentators shared this euphoria and hopefulness about the ICC's ability to so profoundly change the landscape of international justice. See, e.g., James F. Alexander, The International Criminal Court and the Prevention of Atrocities: Predicting the Court's Impact, 54 VILL. L. REV. 1, 1 (2009) (quoting former U.S. Secretary of State John Bolton, who said that the ICC would have no deterrent effect on men like Pol Pot and that giving victims of atrocities hope of ICC deterrence amounts to a cruel joke).

3. The ICC came into existence in July 2002 after the required 60 states ratified the Rome Statute. See generally William A. Schabas, AN Introduction to the INTERNATIONAL CRIMINAL COURT (3d ed. 2007).

4. Press Release, Office of the Secretary-General, Transcript of Press Conference with President Carlo Ciampi of Italy and Secretary-General Kofi Annan in Rome and New York by Video Conference, U.N. Press Release SC/SM/8194 (Apr. 11, 2002).

5. The Coalition for the International Criminal Court (CICC) is a network of NGOs that advocated for the ICC's creation and that continues to advocate for all states to join the court. See The COALITION fOR THE InT'L CRIM. CT. (CICC), http://www.coalition fortheicc.org/ [https://perma.cc/E3S5-FSLW].

6. William R. Pace, Convenor, Coalition for the Int'l Crim. Ct., Statement of the Coalition for the International Criminal Court to the First Assembly of States Parties to the International Criminal Court (Sept. 9, 2002), http://archive.iccnow.org/documents /ciccASP9Sept02.pdf [https://perma.cc/6ZF2-2QQK]. 
Court is to end impunity for perpetrators of the most serious crimes of concern to the international community. ${ }^{7}$

Since the ICC began operating, much scholarly literature has engaged with the question of whether and under what circumstances the ICC can achieve its lofty goals. Critics have identified a variety of structural limitations on the Court's ability to transform international justice. ${ }^{8}$ Most notably, the Court lacks the direct coercive power that facilitates the operation of domestic criminal courts. The Court has no police force to arrest perpetrators ${ }^{9}$ and relies on State cooperation to gather evidence and to bring suspects to the courtroom. ${ }^{10}$ Though the Rome Statute requires its States Parties to comply with requests to provide evidence, ${ }^{11}$ arrest suspects, and surrender suspects, ${ }^{12}$ the ICC cannot coerce compliance. At most, the ICC can find that a State failed to cooperate and refer the matter to external bodies. $^{13}$

Despite these limitations, the ICC has made some strides in ending impunity for serious international crimes. As of October 2017, the ICC's Office of the Prosecutor (OTP) has brought charges against individuals in twenty-five cases based on ten situations. ${ }^{14}$ The ICC has convicted four perpetrators. ${ }^{15}$ In addition, the ICC has

7. Rome Statute, supra note 1, Preamble.

8. Though not a focus of this Article, the Court's limited prosecutorial and financial resources permit the processing of only a handful of cases each year. See, Christopher W. Mullins \& Dawn L. Rothe, The Ability of the International Criminal Court to Deter Violations of International Criminal Law: A Theoretical Assessment, 10 INT'L CRIM. L. REV. 771, 780 (2010) (explaining how the court's budget constrains its ability to open investigations and try cases).

9. See, e.g., Jack Goldsmith \& Steven D. Krasner, The Limits of Idealism, 132 DAEDALUS 47, 55 (2003) (referencing the ICC's lack of a police force as one reason why it is "wishful thinking" that the ICC will "save many lives" in the future).

10. See, e.g., How the Court Works, INT'L CRIM. CT., https://www.icccpi.int/about/how-the-court-works/Pages/default.aspx\#legalProcess (last visited Nov. 5, 2017) [https://perma.cc/3Z7N-VW4W] (stating that the ICC has no police force and must rely on state cooperation). The ICC does not permit trials in absentia except in "exceptional circumstances" in which the accused, while before the Court, repeatedly disrupts proceedings; Rome Statute, supra note 1, art. 63.

11. Rome Statute, supra note 1, art. 86.

12. Id. art. 89.

13. Id. art. 87(7).

14. Some cases have more than one suspect. In total, 41 people have been indicted by the ICC. See Situations Under Investigation, INT'L CRIM. CT., https://www.icccpi.int/pages/situations.aspx (last visited Nov. 5, 2017) [https://perma.cc/9RMY-H24X].

15. See, Press Release, Int'l Crim. Ct., ICC Trial Chamber VIII declares Mr. Al Mahdi Guilty of the War Crime of Attacking Historic and Religious Buildings in Timbuktu and 
used its resources to develop domestic rule of law and encourage States to prosecute perpetrators of international crimes in their domestic courts. 16

It is apparent, however, that the ICC's lack of coercive power has negatively impacted its ability to carry out its functions and achieve its goals; the ICC has suffered several defeats directly linked to State non-cooperation. One notable example is five separate States failing to arrest and surrender President al-Bashir of Sudan after the 2009 issuance of his warrant for arrest. ${ }^{17}$ To date, the warrant remains unexecuted. Kenya, Chad, South Africa, Djibouti, and Uganda welcomed al-Bashir to their countries and allowed him to return to Sudan. ${ }^{18}$

Sentences Him to Nine Years' Imprisonment (Sept. 27, 2016), https://www.icccpi.int/Pages/item.aspx?name=pr1242 [https://perma.cc/636D-3DSP] (referencing the conviction of Al Mahdi); Press Release, Int'l Crim. Ct., Thomas Lubanga Dyilo Sentenced to 14 Years of Imprisonment (July 10, 2012), http://www.icccpi.int/en_menus/icc/press\%20and\%20media/press\%20releases/Pages/pr824.aspx

[https://perma.cc/99MT-7D3N] (referencing the conviction of Thomas Lubanga Dyilo); Press Release, Int'l Crim. Ct., Germaine Katanga Sentenced to 12 Years' Imprisonment (May 23, 2014), http://www.icc-cpi.int/en_menus/icc/press\%20and\%20media /press\%20releases/Pages/pr1008.aspx [https://perma.cc/J875-VVK3] (referencing the conviction of Germaine Katanga); Press Release, Int'l Crim. Ct., ICC Trial Chamber III declares Jean-Pierre Bemba Gombo guilty of war crimes and crimes against humanity (Mar. 21, 2016), https://www.icc-cpi.int/legalAidConsultations?name=pr1200 [https://perma.cc/EJ26$7 \mathrm{WCH}$ ] (regarding the conviction of Jean-Pierre Bemba Gombo). Though the Court has convicted Bemba, Bemba is currently appealing the conviction. See, Prosecutor v. JeanPierre Bemba Gombo, Case No. ICC-01/05-01/08, Public Redacted Version of Appellant's Document in Support of the Appeal (Sept. 28, 2016), https://www.icccpi.int/CourtRecords/CR2016_08242.PDF [https://perma.cc/765Z-NHFJ]

16. Kirsten Ainley, The Responsibility to Protect and the International Criminal Court: Counteracting the Crisis, 91 INT'L AFF. 37, 48-49 (2015) (stating that the ICC "put pressure on the Colombian government to reform its domestic legal system" and promoted domestic proceedings by contacting independent experts and meeting with Colombian officials, judges, prosecutors, NGOs, and victims); see also Fatou Bensouda, ICC Prosecutor, Office of ICC Prosecutor, Statement of ICC Prosecutor, Fatou Bensouda, on the conclusion of the peace negotiations between the Government of Colombia and the Rovolutionary Armed Forces of Colombia - People's Army (Sept. 1, 2016), https://www.icccpi.int/legalAidConsultations?name=160901-otp-stat-colombia [https://perma.cc/NG5B4VXD] (statement from the ICC Prosecutor about how she "supported Colombia's efforts to bring an end to the decades-long armed conflict in line with its obligations under the Rome Statute since the beginning of the [peace] negotiations" and "will continue to do so during the implementation phase").

17. Situation in Darfur, Sudan, The Prosecutor v. Omar Hassan Ahmad Al Bashir, Case Information Sheet, INT'L CRIM. CT. (Apr. 6, 2017), https://www.icc-cpi.int/darfur /albashir/Documents/AlBashirEng.pdf [https://perma.cc/PKR2-MTA7].

18. See, e.g., Peter Leftie \& Kevin Kelly, Storm Over al-Bashir's Surprise Visit, DAILY 
How can an international court achieve compliance with its orders when it lacks power to coerce? This Article looks to the literature on institutional legitimacy to suggest an answer: the ICC needs to build its stock of domestic perception legitimacy, particularly in cases when it intervenes over the State's objection. Domestic perception legitimacy reflects the beliefs of the individuals and communities directly affected by the atrocities investigated by an international tribunal. ${ }^{9}$ When levels of domestic perception legitimacy are high, individuals tend to comply, and push others to comply, with institutional orders because they view the norms advanced by the institution as their own. ${ }^{20}$ With the domestic audience on its side, the ICC would be better positioned to pressure State leaders to comply with their Rome Statute obligations. The corollary is also true: unless the ICC can convince domestic audiences of its legitimacy, those audiences are unlikely to support the Court and push leaders to adopt and adhere to norms of international criminal justice and accountability. $^{21}$

This Article's focus is on underscoring the importance of domestic perception legitimacy when the ICC intervenes over the State's objection - as it did in Kenya when the ICC's OTP brought

NATION (Aug. 28, 2010), http://www.nation.co.ke/Kenya\%20Referendum /Storm\%20over\%20al\%20Bashir\%20/-/926046/998960/-/69nwjj/-/ [https://perma.cc/F6EPH9R5] (discussing Bashir's 2010 visit to Kenya); Xan Rice, Chad Refuses to Arrest Omar al-Bashir on Genocide Charges GUARDIAN (July 22, 2010), https://www.theguardian.com/world/2010/jul/22/chad-refuses-arrest-omar-al-bashir [https://perma.cc/N2DN-M3B8] (discussing Bashir's 2010 visit to Chad); ICC refers Ugan$d a$ and Djibouti to UN for not arresting al-Bashir, DW (July 12, 2016), http://www.dw.com/en/icc-refers-uganda-and-djibouti-to-un-for-not-arresting-al-bashir/a19396326 [https://perma.cc/AUV7-VRHT] (discussing Bashir's visits to South Africa, Uganda, and Djibouti).

19. Stuart Ford, A Social Psychology Model of the Perceived Legitimacy of International Criminal Courts: Implications for the Success of Transitional Justice Mechanisms, 45 VAND. J. TRANSNAT'L L. 405, 406 n. 1, 407 (2012). Ford also explains that domestic perceived legitimacy is not the only perceived legitimacy that is important to the functioning of an international criminal tribunal. For the purposes of receiving funding and other support from the international community, the ICC will also want to achieve international perceived legitimacy. Id. at 407 n.1. This Article addresses only the challenges the court faces in achieving domestic perceived legitimacy.

20. See, e.g., Allen Buchanan \& Robert O. Keohane, The Legitimacy of Global Governance Institutions, 20 ETHICs \& INT'L AfF. 495, 411 (2006); Tom R. Tyler, Psychological Perspectives on Legitimacy and Legitimation, 57 ANN. REV. PSYCHOL. 375, 376-79 (2006).

21. See Jaya Ramji-Nogales, Designing Bespoke Transitional Justice: A Pluralist Process Approach, 32 Mich. J. INT'L L. 1, 12-13 (2010) (explaining that sociological legitimacy - referred to here as domestic perception legitimacy—influences the decision calculus of actors regarding compliance). 
crimes against humanity charges against six high-profile Kenyans in $2010 .{ }^{22}$ This Article does not discuss instances in which a State itself has sought the ICC's assistance. ${ }^{23}$ If a State refers a case, it presumably is prepared to cooperate with the Court, providing it access to the general populace, witnesses, and documentary evidence; the ICC does not need the public to mobilize and demand government cooperation. $^{24}$ In contrast, when the ICC brings a case over a State's objection, domestic mobilization may be a critical factor in whether the government will cooperate with the ICC's efforts.

There are, in theory, ways that the ICC can build its stock of domestic perception legitimacy, encourage the public to embrace rather than distrust ${ }^{25}$ the Court, and induce bottom-up compliance. Chief among them is ensuring that the public is aware of the ICC, its functions, and its goals. Though the ICC devotes some resources to in-person outreach - the gold standard for educating a far-away public - hostile State leaders may, in practice, interfere with ICC personnel's access to the public. Similarly, the Court's civil society surrogates may face State-imposed obstacles or retribution. Hostile State leaders can use their access and communication ${ }^{26}$ advantages to de-

22. See Press Release, Int'l Crim. Ct., Kenya's Post Election Violence: ICC Prosecutor Presents Cases Against Six Individuals for Crimes Against Humanity (Dec.15, 2010), http://www.icc-

cpi.int/en_menus/icc/press\%20and\%20media/press\%20releases/press\%20releases\%20(2010 )/Pages/pr615.aspx [https://perma.cc/C2VJ-HCP9]; Anthony Kariuki \& Oliver Mathenge, Ocampo Names Kenya Chaos Suspects, DAILY NATiON (Dec. 15, 2010), http://www.nation.co.ke/News/politics/Ocampo\%20names\%20Kenya\%20chaos\%20suspects /-/1064/1072864/-/15awvwuz/-/index.html [https://perma.cc/X3GU-E3ZX].

23. The Rome Statute does not expressly provide for self-referrals. Indeed, its drafters did not anticipate that States would readily surrender their national criminal jurisdiction the Court. Self-referral, which "promised better results in the form of enhanced state cooperation," was developed at the behest of the first ICC Prosecutor and through the ICC's early practice. The Ugandan government delivered the ICC its first self-referred situation. Despite the potential for enhanced State cooperation, some have cast doubt on the prudence of relying heavily on self-referral. See Andreas Muller \& Ignaz Stegmiller, Self-Referrals on Trial: From Panacea to Patient, 8 J. INT'L CRIM. JUST. 1267, 1269 (2010).

24. But see id. at 1286 (noting that enhanced cooperation "cannot be taken for granted" in self-referred cases because a State's viewpoint of a situation may change over time).

25. See Victor Peskin, Courting Rwanda: The Promises and Pitfalls of the ICTR Outreach Programme, 3 J. INT'L CRIM. J. 950, 953 (2005) (arguing that unlike long-established courts that enjoy broad legitimacy, domestic audiences where crimes occurred will often view international criminal courts as alien because of "their perceived challenge to state sovereignty, domestic conceptions of justice and the belief of a government or society in its own innocence").

26. State leaders, unlike foreign ICC personnel, would not face the difficulties of crosscultural communication. See, e.g., Hillary Anger Elfenbein \& Nalini Ambady, Universals 
fine and impugn the Court. A public inundated with, and persuaded by, negative rhetoric will not support the ICC's efforts to advance international criminal justice and accountability. What can be done to avoid this unhappy outcome?

This Article proceeds as follows: Part I provides some background on the creation of the ICC, its goals, and its institutional structure. Part I then explains why domestic perception legitimacy is essential to the ICC's ability to deliver justice and accountability when the ICC intervenes over a State's objection. Part II explores various factors that may influence the perceived legitimacy of international tribunals and considers those factors in the context of ICC intervention over a State's objection. Part III uses Kenya as a case study to illustrate the challenges of building domestic perception legitimacy. Drawing from ICC documents, news reports, and interviews conducted by the Author, this Article demonstrates how Kenyan leaders used their access and communication advantages to wage a disinformation campaign against the ICC. A sufficent number of Kenyans were persuaded by the campaign and backed their leaders instead of supporting the ICC's efforts to provide justice for victims of atrocities.

This Article concludes that the ICC likely will not be able to build domestic perception legitimacy without a concerted effort by the funding States Parties, the ICC itself, and civil society organizations. With enough time and effort, these actors can advance the ICC's embodied norms of international criminal justice and accountability so that these norms are internalized by domestic audiences.

\section{The ICC AND Its DOMESTIC PERCEPTION LEGITIMACY}

\section{A. Background on the ICC}

By committing to the Rome Statute, States grant the Court automatic jurisdiction over genocide, crimes against humanity, and war crimes. ${ }^{27}$ The Rome Statute provides for three ways that the ICC can

and Cultural Differences in Recognizing Emotions, 12 CuRRENT DiRECTIONS IN PSYCH. SCI. (2003) 159, 161 (noting that one barrier to cross-cultural communication is that persons of the same culture are "generally more accurate in recognizing emotions expressed by members of their own culture than in recognizing emotions expressed by members of a different cultural group"); Nancy J. Adler \& John L. Graham, Cross-Cultural Interaction: The International Comparison Fallacy?, 20 J. OF INT'L BUS. STUD. 515, 517 (citing to research showing that when cultural differences between individuals are great, barriers to communication and misunderstandings are more likely).

27. See Rome Statute, supra note 1, arts. 5-8, 11, 12(1). 
exercise jurisdiction: first, States Parties may themselves refer situations to the Prosecutor; ${ }^{28}$ second, the ICC's Prosecutor may initiate investigations proprio motu, or on her own motion and with the approval of the Court; ${ }^{29}$ and third, the United Nations Security Council, acting under Chapter VII of the UN Charter, may refer situations to the ICC when it concludes that one or more crimes within the Court's jurisdiction have been committed. ${ }^{30}$ The Security Council is not limited to referring situations where the crimes were committed on the territory of a State Party or committed by the national of a State Party. ${ }^{31}$ Although the Security Council may refer situations, the ICC operates without oversight, and the Security Council has no veto power over investigations or prosecutions. ${ }^{32}$ The Rome Statute expressly provides that neither functional nor personal immunity bars the Court's exercise of jurisdiction. ${ }^{33}$

The Rome Statute envisions the ICC as a court of last resort. The principle of complementarity, which recognizes States' responsibility and right to prosecute crimes, defines when cases are admissible to the Court. ${ }^{34}$ A case is only admissible if the Prosecutor proves that the State with domestic jurisdiction over the crimes has shown "inaction",35 or is "unwilling or unable" to investigate or prosecute. $^{36}$

When a State fails to investigate or prosecute - that is, in cases of complete inaction - the question of unwillingness or inability does not arise. ${ }^{37}$ To determine if a State has been inactive, the Court

28. Id. arts. 13(a), 14.

29. Id. arts. 13(c), 15 .

30. Id. art. 13(b).

31. Id. art. $12(2),(3)$.

32. See Lionel Yee, The International Criminal Court and The Security Council: Articles 13(b) and 16, in The International Criminal Court: The Making of the Rome StatuTe 143-52 (Roy S. Lee, ed., 1999); Christopher Rudolph, Constructing an Atrocities Regime: The Politics of War Crimes Tribunals, 55 INT'L ORG. 655, 679-80 (2001) (explaining that while the Security Council members do not have a veto power, a unanimous vote by the Security Council may defer a prosecution).

33. Rome Statute, supra note 1, at art. 27.

${ }^{34}$. Dragana Radosavljevic, An Overview of the ICC Complementarity Regime, 1 USAK Y.B. INT'L POL. \& L. 125, 129 (2008).

35. Appeals Chamber, Judgment on the Appeal of Mr. Germain Katanga against the Oral Decision of Trial Chamber II of 12 June 2009 on the Admissibility of the Case, ICC01/04- 01/07-1497, para. 78.

36. Rome Statute, supra note 1, Preamble and art. 17(1)(a).

37. Appeals Chamber, Judgment on the Appeal of Mr. Germain Katanga against the Oral Decision of Trial Chamber II of 12 June 2009 on the Admissibility of the Case, ICC01/04- 01/07-1497, para. 78, https://www.icc-cpi.int/CourtRecords/CR2009_06998.PDF 
considers whether a particular perpetrator has been investigated or prosecuted for a particular crime. ${ }^{38}$ Thus, if a State proceeds against some but not all perpetrators, or charges a perpetrator with an offense unrelated to the atrocities committed, that State may be inactive. The ICC only considers whether a State is unwilling or unable to carry out genuine proceedings once that State has already begun its investigation or prosecution. 39

Unwillingness includes instances in which national proceedings are a sham or are otherwise inconsistent with an intention to bring a perpetrator to justice. ${ }^{40}$ The Rome Statute expressly provides that unjustifiably delayed or biased proceedings may exhibit unwillingness. ${ }^{41}$ This basis for admissibility recognizes that some domestic proceedings may be for "show" and not intended to hold perpetrators accountable. $^{42}$ It also recognizes that domestic proceedings with serious procedural defects "defeat the goals of the criminal process" and leave justice "entirely illusory." 43 " Inability to proceed includes instances in which a State, because of the shortcomings of its judicial system, cannot obtain the accused, cannot obtain necessary evidence, or is otherwise unable to carry out the proceedings. ${ }^{44}$ A State that lacks the necessary judicial and enforcement personnel, or that lacks substantive and procedural penal legislation, might be unable to prosecute in accordance with the Rome Statute. ${ }^{45}$

The ICC, rather than any domestic court, determines whether a State has been inactive or is unwilling or unable to proceed. Setting aside cases of self-referral, one can imagine that this initial decision does little to engender the goodwill of States with domestic jurisdiction over a crime. Should a State disagree with the ICC's decision, its

[https://perma.cc/64XV-36VU]

38. Gideon BoAs et AL., InTERnAtional CRiminal Procedure 73-80 (2011).

39. Rome Statute, supra note 1; Christoph Safferling, International Criminal Procedure 99-100 (2012); International Criminal Court Office of the Prosecutor, Informal Expert Paper: The Principle of Complementarity in Practice 7-8 (2003), https://www.icccpi.int/NR/rdonlyres/20BB4494-70F9-4698-8E30-

907F631453ED/281984/complementarity.pdf [https://perma.cc/TQ7W-XGTD]

40. Rome Statute, supra note 1, art. 17(2).

41. Id.

42. John T. Holmes, The Principle of Complementarity, in THE INTERNATIONAL Criminal Court: The Making of the Rome Statute 41, 50 (Roy Lee ed., 1999)..

43. Frederic Megret \& Marika Samson, Holding the Line on Complementarity in Libya, 11 J. INT'L CRIM. JUST. 571, 586 (2013).

44. Rome Statute, supra note 1, art. 17(3).

45. Informal Expert Paper: The Principle of Complementarity in Practice, supra note 39 , at 15 . 
leaders and members of the public might take offense and refuse to cooperate. The ensuing noncompliance would pose unique challenges for the ICC.

The ICC faces structural limitations that distinguish it from domestic justice institutions. Unlike domestic prosecutors, the ICC's Prosecutor has no police force to serve as an investigatory and enforcement arm. The ICC must rely on State consent and cooperation to obtain evidence and for the arrest and surrender of suspects. ${ }^{46}$ At most, the Prosecutor and Court may issue requests to, seek cooperation from, and enter into arrangements with State and non-State actors. ${ }^{47}$ Though the Rome Statute provides that States Parties must comply with ICC requests, ${ }^{48}$ the ICC has limited power to enforce compliance. It is only empowered to issue findings of State noncompliance and refer the matter to the Assembly of States Parties or to the Security Council, provided the Council first referred the matter to the ICC. ${ }^{49}$ To date, the Court's issuance of a finding and referral has not once persuaded a State to comply or prompted the Security Council to take action.

Although some States have cooperated with the ICC and assisted in the arrest and surrender of suspects, ${ }^{50}$ cooperation is not the norm. As noted, States Parties have repeatedly failed to arrest President al-Bashir, despite a 2009 arrest warrant charging al-Bashir with crimes against humanity, war crimes, and genocide based on violent acts committed by his government forces against civilians. ${ }^{51}$ The arrest warrant specifies that al-Bashir played an essential role in coor-

46. See Alexander K.A. Greenawalt, Justice without Politics? Prosecutorial Discretion and the International Criminal Court, 39 N.Y.U. J. Of INT'L L. \& POL. 583, 606 (2007) (stating that the ICC "lacks a built-in enforcement mechanism and is thus highly dependent upon the cooperation and assistance of political powers").

47. Rome Statute, supra note 1, arts. 54(2)(b), (3)(a-d), 87.

48. Id. arts. 86, 89. The Rome Statute provides one exception to its general requirement of compliance. States Parties are permitted to deny requests for the production of evidence relating to national security. Id. Art. 93(4).

49. Id. art. 87(7)

50. See, e.g., Press Release, Int'l Crim. Ct., Dominic Ongwen transferred to The Hague (Jan. 20, 2015), https://www.icc-cpi.int/pages/item.aspx?name=pr1084 [https://perma.cc/RM6E-T2XZ] (discussing the cooperation of the United Nations and various states in the surrender and transfer to the ICC of Lord's Resistance Army commander, Dominic Ongwen); International Justice Monitor Summaries, Jean-Pierre Bemba Gombo, https://www.ijmonitor.org/jean-pierre-bemba-gombo-background/ [https://perma.cc/VDA4QPSJ] (discussing the Belgian authorities' assistance and cooperation in arresting and transferring to The Hague Jean-Pierre Bemba Gombo, who was charged with crimes against humanity and war crimes committed during conflict in the Central African Republic).

51. Situation in Darfur, supra note 17. 
dinating a plan for government forces to murder, torture, and rape civilians of particular ethnicities. ${ }^{52}$ Still, numerous ICC Member States have welcomed al-Bashir into their territory and subsequently allowed him to return to Sudan. ${ }^{53}$

The events surrounding al-Bashir's June 2015 visit and escape from South Africa exemplify the ICC's structural limitations in obtaining cooperation from recalcitrant States. The South African government permitted al-Bashir to leave the state even though the South African Supreme Court had issued an order-in response to the ICC's arrest warrant - banning al-Bashir's departure. ${ }^{54}$ Shortly after al-Bashir's departure, an ICC Pre-Trial Chamber considered making a finding of non-cooperation under Article 87(7). The ICC sought South Africa's views on the events surrounding al-Bashir's visit, but South Africa requested an extension for submission of its views until its domestic proceedings relating to the visit concluded. ${ }^{55}$ The domestic proceedings concluded in November 2016, and the South African Supreme Court found that the government had defaulted on its obligations under the Rome Statute. ${ }^{56}$ In July 2017, the ICC's Pre-Trial Chamber II concluded the same. ${ }^{57}$ The Pre-Trial Chamber, however, refrained from referring South Africa's noncooperation to the Assembly of States Parties or the Security Council. It decided that referral was "not warranted as a way to obtain cooperation" because the Security Council had not acted on previous referrals of other States Parties that had failed to arrest al-Bashir. ${ }^{58}$

52. Id.

53. See, e.g., Leftie \& Kelly, supra note 18; Rice, supra note 18; ICC refers Uganda and Djibouti to UN for not arresting al-Bashir, supra note 18.

54. South African government loses appeal over failure to arrest Bashir, REUTERS (March 15, 2016), http://www.reuters.com/article/us-safrica-icc-idUSKCNOWH19Y [https://perma.cc/MD45-HXRF]

55. ICC Office of the Prosecutor, Twenty-Fourth Report of the Prosecutor of the International Criminal Court to the United Nations Security Council Pursuant to UNSCR 1593 (2005), II 7 (Dec. 13, 2016), https://www.icc-cpi.int/itemsDocuments/161213-otp-rep-24darfur_Eng.pdf [https://perma.cc/P8AB-8ESD].

56. Id. II 6.

57. See Prosecutor v. Omar Hassan Ahmad Al-Bashir, ICC-02/05-01/09, Decision under article 87(7) of the Rome Statute on the non-compliance by South Africa with the request by the Court for the arrest and surrender of Omar Al-Bashir, III 107-08 (July 6, 2017) https://www.icc-cpi.int/CourtRecords/CR2017_04402.PDF [https://perma.cc/NV3H-3ZTP] (concluding that as a State Party to the Rome Statute, South Africa was obligated to arrest and surrender al-Bashir even if customary international law affords immunity from criminal prosecution to heads of state).

58. See id. III 135-140 (refusing to refer the non-cooperation of South Africa to the Assembly of States Parties or the Security Council). 
Though the ICC is empowered to request State cooperation and make findings about non-cooperation, requests and findings have proven insufficient to induce compliance when the Court intervenes over a State's objection.

\section{B. The Need for Domestic Perception Legitimacy}

How can an international court induce compliance with its decisions when it lacks power to coerce? This Article argues that international courts can benefit from bottom-up compliance mechanisms, or public pressure. ${ }^{59}$ It focuses on how the ICC can, and indeed must, build its stock of domestic perception legitimacy when it intervenes in States that are unable or unwilling to prosecute. ${ }^{60}$

Legitimacy refers to an institution's right to govern and has both objective and subjective dimensions. ${ }^{61}$ Objectively, an institution is legitimate if its operations and processes are consistent with normative performance criteria, like the proportionality of punishments to their crime or procedural fairness. ${ }^{62}$ In the subjective and sociological sense, an institution is legitimate when the affected pub-

59. Though written in an article about negotiations rather than compliance, Robert Putnam's words are equally applicable here. "At the national level, domestic groups pursue their interests by pressuring the government to adopt favorable policies, and politicians seek power by constructing coalitions among those groups. At the international level, national governments seek to maximize their own ability to satisfy domestic pressures, while minimizing the adverse consequences of foreign developments. Neither of the two games can be ignored by central decision-makers, so long as their countries remain interdependent, yet sovereign." Robert Putnam, Diplomacy and Domestic Politics: The Logic of Two-Level Games, 42 INT'L ORG. 427, 434 (1988).

60. See Ramji-Nogales, supra note 21, at 12-13 (explaining that sociological legitimacy-referred to here as domestic perception legitimacy-influences the decision calculus of actors regarding compliance).

61. See Buchanan \& Keohane, supra note 20, at 405 (referencing the "normative and sociological meanings" of legitimacy).

62. Erik Voeten, Public Opinion and the Legitimacy of International Courts, 14 THEORETICAL INQUIRIES IN L. 411, 414 (2013) (distinguishing objective and subjective conceptions of legitimacy); David Luban, Fairness to Rightness: Jurisdiction, Legality, and the Legitimacy of International Criminal Law 13 (Geo. L., Working Paper, 2008), http://scholarship.law.georgetown.edu/cgi/viewcontent.cgi?article=1069\&context=fwps_pap ers [https://perma.cc/37PA-S33K] (explaining that when an institution conforms to certain objective requirements for legitimate decision making, it possesses "actual" legitimacy); Allison Marston Danner, Enhancing the Legitimacy and Accountability of Prosecutorial Discretion at the International Criminal Court, 97 AM. J. INT'L L. 510, 536 (2003) (explaining that when an institution conforms to certain objective requirements for legitimate decision making, it possesses "actual" legitimacy). 
lic widely believes that the institution has the right to rule. ${ }^{63}$ As Erik Voeten notes, beliefs about an institution "may be influenced by the degree to which institutional behavior meets normative or positive performance criteria, but not necessarily so."64 Even if a court operates fairly, "the public may deem the institution illegitimate (or vice versa) for reasons that may seem unfair or arbitrary to normative theorists." $" 65$ Allison Danner has argued that the ICC may suffer from an objective and subjective legitimacy disconnect. ${ }^{66}$

The legitimacy disconnect is troubling because domestic perceptions of international institutions influence State compliance, perhaps more so than whether institutions operate fairly according to normative performance criteria. When the public believes an international institution is legitimate, it will "support the continued functioning of the institution" even if it disagrees with particular decisions. ${ }^{67}$ Moreover, the public will defend the institution and encourage compliance with the institution's decisions. ${ }^{68}$ When an institution does not enjoy a high degree of public support, it is easier for government officials to ignore or otherwise fail to comply with its decisions. ${ }^{69}$

Domestic perception legitimacy, a form of subjective legitimacy, is particularly important in the international context because many international institutions are designed without mechanisms to coerce compliance. ${ }^{70}$ When an institution cannot force compliance,

63. Buchanan \& Keohane, supra note 20, at 405.

64. Voeten, supra note 62, at 414.

65. Id.

66. See Danner, supra note 62, at 536 (positing that while actual and perceived legitimacy may coincide, "it is possible that the Prosecutor may act legitimately, but that outside entities will not perceive him to be acting legitimately").

67. James L. Gibson \& Gregory A. Caldeira, The Legitimacy of Transnational Legal Institutions: Compliance, Support, and the European Court of Justice, 39 AM. J. PoL. SCI. 459, 460 (1995); see also Yonatan Lupu, International Judicial Legitimacy: Lessons from National Courts, 14 THEORETICAL INQUIRIES IN L. 437, 441 (2013) (noting the close relationship between legitimacy and diffuse support).

68. See, e.g., Gibson \& Caldeira, supra note 67, at 460; Gregory A. Caldeira \& James L. Gibson, The Legitimacy of the Court of Justice in the European Union: Models of Institutional Support, 89 AM. POL. SCI. REV. 356, 363 (1995) (finding that a supportive public would defend the European Court of Justice against abolition even if the institution "started making a lot of decisions that most people disagree with").

69. Voeten, supra note 62, at 418-19 (citing the British public's lack of support for the European Court of Human Rights to help explain the British government's failure to comply with that court's decision on prisoner voting rights); Caldeira \& Gibson, The Legitimacy of the Court of Justice in the European Union, supra note 68, at 363 (reporting the results of their study on public perceptions of the European Court of Justice).

70. Daniel Bodansky, Legitimacy in International Law and International Relations, in 
the domestic audience must advocate for compliance. When an institution enjoys high levels of domestic perception legitimacy, the public will step in because it believes in, and views as its own, the norms the institution advances. ${ }^{71}$

For the ICC, high levels of domestic perception legitimacy would mean that the public embraces norms of international criminal justice and accountability. If the public believes in those norms, it should support, or at least not interfere with, ICC efforts to investigate and prosecute. ${ }^{72}$ When those norms are threatened by government action or inaction, the public should also be willing to mobilize and encourage its leaders to respond to ICC requests and cooperate with the Court and Prosecutor. Domestic audience mobilization can lead recalcitrant governments to comply with their international obligations, ${ }^{73}$ but mobilization is contingent on domestic perception legitimacy. ${ }^{74}$

InTERDisCiPLINARy PERSPECTIVES ON INTERNATIONAL LAW AND INTERNATIONAL RELATIONS: The State of the Art 321, 328 (Jeffrey L. Dunoff \& Mark A. Pollack eds., 2013). See also Stephen Chaudoin \& Terrance Chapman, Contingent Public Support for International Legal Institutions 6 (March 21, 2017) (unpublished manuscript) (on file with the Columbia Journal of Transnational Law) (arguing that "public attitudes are central to the functioning and effectiveness of international courts precisely because those institutions rely on government consent and cooperation").

71. See Tyler, supra note 20, at 376-79. Largely independent of the public's belief about institutional legitimacy, some States abide by institutional authority because of international, strategic self-interest, e.g. international coordination benefits or reputational effects. This is consistent with Robert Putnam's two-level game theory, inasmuch as compliance can still be in the distrustful public's best interest or can avoid some adverse international consequence. States' internationally-oriented self-interest in complying with ICC requests is largely beyond the scope of this Article, though the concept will be revisited in the concluding paragraphs. Buchanan \& Keohane, supra note 20, at 408-11.

72. Buchanan \& Keohane, supra note 20,at 407 (stating that when domestic perception legitimacy is high, individuals should "support or at least refrain from interfering" with the institution's decisions).

73. Beth A. Simmons, Mobilizing for Human Rights: International LaW in DOMESTIC POLITICS 152-153 (2009) (producing evidence supporting the importance of domestic mobilization efforts to induce state compliance with international human rights treaties).

74. Commentators seem to agree that international criminal tribunals are more likely to be successful in fulfilling their goals of providing justice and accountability if they have high levels of domestic perception legitimacy. See, e.g., Lupu, supra note 67. at 443; Laura A. Dickinson, The Promise of Hybrid Courts, 97 AM. J. INT'L L. 295, 306 (2003) (discussing how hybrid courts might help to increase the perceived legitimacy of the ICC among local populations); William Burke-White, Regionalization of International Criminal Law Enforcement: A Preliminary Exploration, 38 TEX. INT'L L.J. 729, 736737 (2003) (“For a national government to be politically able to cooperate with an international criminal tribunal, the tribunal must be perceived as legitimate by the affected national polity."). See also Gib- 


\section{The Factors Influencing Domestic PeRCEPTION LegitimaCy}

How might the ICC build domestic perception legitimacy? It is not an easy task. International courts tend to be far away and foreign. $^{75}$ International courts must overcome awareness and understanding hurdles that can prevent domestic audiences from knowing enough about court purposes and processes to feel a sense of "ownership" - that the court is "theirs," as opposed to an "alien" body infringing on State sovereignty. ${ }^{76}$

Reviewing the literature, this Article identifies several factors that can positively enhance the public's perceptions of an objectively legitimate international court: (1) the proximity of the court to the affected populace; (2) the quantity and quality of the court's outreach initiatives to increase domestic awareness and understanding of the court; (3) the nature of the domestic population's other opportunities to gain awareness and understanding of the court and how it operates; and (4) the degree to which the populace trusts its own judicial institutions. This Section discusses each of these factors below and explores the extent to which they provide opportunities for the ICC to engender high levels of domestic perception legitimacy in States where the Court intervenes over government objection. This Part concludes that the ICC's most viable, though still difficult, avenue for increasing domestic perception legitimacy is conducting inperson outreach.

son \& Caldeira, supra note 67, at 461, 483 (suggesting that the European Court of Justice's lack of domestic perceived legitimacy among citizens of the European Union helps explain why few people in those countries are willing to accept a decision with which they do not agree).

75. See Lupu, supra note 67 , at 440 (noting that while many national courts seem to have achieved high levels of perceived legitimacy, international courts often find it difficult to establish their legitimacy with domestic audiences); Voeten, supra note 62, at 415 (noting that supranational justice institutions do not have the same ability to influence domestic audiences and "build a stock of legitimacy through opinions that cater to specific constituencies" as do domestic courts); Chaudoin \& Chapman, supra note 70, at 3 (stating that "building legitimacy is a challenging enterprise for international courts, one that is highly context specific and subject to contestation across time and space").

76. See Peskin, supra note 25, at 953 (arguing that unlike long-established courts that enjoy broad legitimacy, domestic audiences where crimes occurred will often view international criminal courts as alien because of "their perceived challenge to state sovereignty, domestic conceptions of justice and the belief of a government or society in its own innocence"). 


\section{A. Proximity of the Court to the Populace}

One way for an international criminal court to build domestic perception legitimacy is by locating itself in or near the State where the crimes occurred. When an international court sits in the State where the atrocities occurred, victims may observe trials. Members of the public, as well as journalists publishing information for local consumption, can also see firsthand how the court functions. ${ }^{77}$ Though not all citizens will attend the proceedings of a proximatelylocated court, "[v]ictims' families and friends, or even ordinary lower income citizens, are more likely to attend proceedings if what is involved is a short bus ride away rather than an international odyssey." 78 Locating a court in close proximity to the affected populace allows individuals to see the court in action, better understand how the court operates, and develop a sense of ownership over proceedings.

Hybrid courts' experience supports this theory. U.N. officials have reported that "tens of thousands" attended proceedings before the Extraordinary Chambers in the Courts of Cambodia (ECCC) and that "hundreds of thousands more" followed along on radio or television. $^{79}$ A 2008 survey of 250 villages from each of Cambodia's provinces found that the majority of adults had at least a basic understanding of the ECCC. ${ }^{80}$ Despite NGOs' and scholars' misgivings about the ECCC's objective legitimacy, ${ }^{81}$ the ECCC enjoys high levels of subjective legitimacy in Cambodia. ${ }^{82}$

77. See Etelle R. Higonnet, Restructuring Hybrid Courts: Local Empowerment and National Criminal Justice Reform, 23 ARIZ. J. INT'L \& COMP. L. 347, 363 (2006).

78. Id. at 363.

79. Miguel de Serpa Soares, Under-Secretary-General for Legal Affairs, U.N. Office of Legal Affairs, Pledging Conference in Support of the Extraordinary Chambers in the Courts of Cambodia (ECCC) Statement (Nov. 7 2013), http://legal.un.org/ola/media/ info_from_lc/mss/speeches/MSS_ECCC_Pledging_Conference_5-Nov-2013.pdf [https://perma.cc/P24C-4Q8V]

80. Phuong Pham et al., So We Will Never Forget: A Population-Based Survey on Attitudes About Social Reconstruction and the Extraordinary Chambers in the Courts of Cambodia 40 (2008) (finding that at least $61 \%$ of surveyed Cambodians knew enough about the ECCC to have informed expectations about the ECCC's ability to process its caseload and deliver international criminal justice and accountability).

81. See, e.g., Wayne Sandholtz, Creating Authority by the Council: the International Criminal Tribunals, in The UN Security Council AND the Politics of International AutHORITY 150 (Bruce Cronin \& Ian Hurd eds, 2008).

82. Pham, supra note 80 , at 39 (finding that $87 \%$ of surveyed Cambodians believe that the ECCC should be involved in responding to the atrocities that took place under than Khmer Rouge). 
In contrast, when courts are located far from the scene of the atrocities, domestic populations might be less trusting of, and might feel less of a connection to, judicial proceedings. ${ }^{83}$ Ethnographic research shows that legal professionals in Bosnia and Herzegovina were suspicious of, and ill-informed about, the International Criminal Tribunal for the Former Yugoslavia - in large part because of the ICTY's location in The Hague rather than the Balkans. ${ }^{84}$

The ICC could hold trials within situation States to increase its chances of persuading domestic audiences of its legitimacy. The Rome Statute permits the Court to sit regionally. ${ }^{85}$ To date, however, the ICC has held its hearings and trials in The Hague. Despite its domestic perception legitimacy benefits, sitting regionally would have serious drawbacks. Sitting regionally would impose additional costs on the under-resourced ${ }^{86}$ ICC, as Court personnel would have to move or travel to the situation State, potentially for years. ${ }^{87}$ For cases in which the ICC is proceeding over government objection, holding the trials in the national jurisdiction could pose safety risks to

83. See Dickinson, supra note 74 , at 302.

84. See Laurel Fletcher \& Harvey Weinstein, Justice, Accountability and Social Reconstruction: An Interview Study of Bosnian Judges and Prosecutors, 18 BERKELEY J. INT'L L. 102, 136-40 (2000) (noting complaints about the use of foreign expert witnesses with no personal connection to the cases, the way in which investigations and prosecutions were prioritized, the limited communication with domestic audiences, the expense and delay of remote trials, and the inaccessibility of the venue for families awaiting trial).

85. See Burke-White, supra note 74 , at 750-51 (citing to Rome Statute, supra note 1, at art. 3 which provides that "The Court may sit elsewhere, whenever it considers it desirable, as provided in this Statute").

86. See, e.g., Lilian Ochieng \& Simon Jennings, International Criminal Court Secures Budget Increase, DAILY NATION (Jan. 17, 2014), http://www.nation.co.ke/news/International-Criminal-Court-Budget-Increase/-

/1056/2150244/-/e7oca3/-/index.html [https://perma.cc/NYA2-7HXZ] (quoting an expert international justice as stating that the ICC "operates on a shoestring budget"); Jonathan O’Donohue, International Criminal Court at Risk, Human Rights Watch (May 6, 2015), https://www.hrw.org/news/2015/05/06/international-criminal-court-risk

[https://perma.cc/5RV6-M9Z8] (noting that because of the ICC's tight budget, Prosecutor Bensouda said she has had to scale down resources for investigating crimes in Libya and to delay investigations into crimes committed in the Ivory Coast).

87. Trials can last for years. For example, the trial proceedings in the ICC's case against Thomas Lubanga occurred over at two-year period. The prosecution presented its evidence between January and Summer 2009. The defense case started in January 2010 and ended in April 2011. See Human Rights Watch, First Verdict at the International Criminal Court: The Case of the Prosecutor vs. Thomas Lubanga Dyilo, Questions AND ANSWERS (2012), https://www.hrw.org/sites/default/files/related_material/ 2012_DRC_Lubanga.pdf [https://perma.cc/W4PY-K55T]. 
judges and other personnel. ${ }^{88}$ The ICC may have to provide additional and costly security. Finally, some national jurisdictions may lack sufficient courtroom facilities to provide seating for public viewing and to meet the technological needs of mass atrocity trials.

Sitting close to the scene of the atrocities is an avenue the ICC could pursue in the future, but the Court would have to weigh that decision carefully and the Assembly of States Parties may have to increase the ICC's budget. Though the budget can be increased, States already committed to capping the ICC's budget ${ }^{89}$ would have to be persuaded that additional funding would bear results.

\section{B. Quantity and Quality of the Court's Outreach}

An international criminal court may also be able to enhance domestic perception legitimacy through significant in-person outreach. ${ }^{90}$ Outreach can raise public awareness and understanding of a tribunal's work, ${ }^{91}$ and may even foster a sense of ownership among members of the public. The International Center for Transitional Justice has explicitly linked outreach to legitimacy, stating that the "final aims of outreach programs should be to promote public engagement

88. Threats in such cases are not uncommon. In the trial against former Guatemalan dictator Rios Montt, charging him with crimes against humanity and genocide, judges and prosecutors received threats of physical harm from Guatemalan army associates operating under the leadership of Guatemalan President General Otto Perez Molina. Genocide Trial of Former Dictator Rios Montt Suspended After Intervention by Guatemalan President, DEMOCRACY Now (April 19, 2013), https://www.democracynow.org/2013/4/19/genocide _trial_of_former_dictator_ros [https://perma.cc/M94K-ANPY].

89. Coalition for the International Criminal Court, Annual ICC Assembly: States Hold Ground on ICC, But Serious Challenges Remain (Dec. 5, 2016), http://www.coalitionfortheicc.org/news/20161205/annual-icc-assembly-states-hold-groundicc-serious-challenges-remain [https://perma.cc/G77J-J8SH] (noting that some of the most powerful and wealthy states wanted to impose a zero-growth budget increase on the ICC in 2017)..

90. The International Center for Transitional Justice defines "outreach" as "a set of tools - the combination of materials and activities - that a [transitional justice] measure puts in place to build direct channels of communication with affected communities, to raise awareness of the justice process and promote understanding of the measure." CLARA RAMIREZ BARAT, INTERNATIONAL CENTER FOR TRANSITIONAL JUSTICE, MAKING AN IMPACT: Guidelines on Designing and Implementing Outreach Programs for Transitional JustiCE, 7 (2011), https://www.ictj.org/sites/default/files/ICTJ-Global-Making-Impact2011-English.pdf [https://perma.cc/34ZR-ASPC].

91. See, e.g., Higonnet, supra note 77, at 418-19 (suggesting that one reason Rwandans perceived the ICTR negatively was due to limited or bad outreach efforts); Jane E. Stromseth, Pursuing Accountability for Atrocities After Conflict: What Impact on Building the Rule of Law?, 38 GEO. J. INT'L L. 251, 260-61, 281 (2007). 
and ownership of the justice process, thereby contributing to building its legitimacy and lasting impact." 92 Absent outreach, especially for remotely-located courts, the public may have few opportunities to learn how a court truly functions. Commentators cite the ICTY's sixyear lag in commencing outreach as one reason why domestic audiences believed the tribunal was biased and illegitimate. ${ }^{93}$ Without ICTY outreach, local media and politicians had captive domestic audiences to which they could spread disinformation about the tribunal. $^{94}$

The ICC does have a designated Public Information and Outreach Section, which maintains field offices in or near the States in which the ICC has active investigations. ${ }^{95}$ The ICC has emphasized that "[p]eople most affected by the crimes have the right to understand, to participate in, and to have a sense of ownership of the justice process." $" 96$ Nevertheless, to spread awareness of the Court, the ICC has primarily used mass media communications, rather than inperson outreach. ${ }^{97}$ Data collected in 2009 show that this approach, at least in the Central African Republic, disproportionately reached wealthy, educated men but not information-poor groups that rely on "interpersonal communication channels at marketplaces or other social gatherings." 98 The communities most likely to include witnesses to, or victims of, atrocities - displaced populations, minority groups suffering discrimination, former combatants, etc.- - are those least likely to benefit from the ICC's mass media communications. ${ }^{99}$

92. Barat, supra note 90 , at 7.

93. See, e.g., Janine Natalya Clark, International War Crimes Tribunals and the Challenge of Outreach, 9 INT'L CRIM. L. REV. 99, 104-05 (2009).

94. Mark Ellis, The Contribution of Non-Governmental Organizations to the Creation of International Criminal Tribunals, in Research Handbook on International Criminal Law 163 (Bartram Brown ed., 2011).

95. Int'l Crim. Ct., Proposed Programme Budget for 2017 of the International Criminal Court, 165 https://asp.icc-cpi.int/iccdocs/asp_docs/ASP15/ICC-ASP-15-10-ENG.pdf [https://perma.cc/L3X4-QYRE] (listing field offices in CAR, Cote d'Ivoire, Uganda, Georgia, Mali, and Kenya).

96. Int'l Crim. Ct., Interacting with Communities Affected by Crimes, https://www.icccpi.int/about/interacting-with-communities?ln=en (last visited Nov. 5, 2017) [https://perma.cc/9NUV-JXAQ]

97. Patrick Vinck \& Phuong N. Pham, Outreach Evaluation: The International Criminal Court in the Central African Republic, The InT'L J. Of Transitional Just., 1, 17 (2010), https://hhi.harvard.edu/sites/default/files/publications/outreach-evaluation.pdf [https://perma.cc/A74Z-ESQA]

98. Id. at 20-21.

99. Id. 
Ideally, the ICC's efforts would follow Victor Peskin's engagement model of outreach. ${ }^{100}$ This model moves beyond merely making the tribunal's work more comprehensible to the public. Engagement envisions in-person ${ }^{101}$ interaction, contact, and dialogue between tribunal personnel and the public through forums like town hall meetings. Through these forums, tribunal personnel can highlight the institution's process, goals, and accomplishments while addressing any perceived shortcomings. ${ }^{102}$ This was the approach taken by the Special Court for Sierra Leone (SCSL) in its outreach program, referred to as the "gold standard" of tribunal outreach initiatives. ${ }^{103}$ The SCSL Registrar and Prosecutor held town hall meetings throughout Sierra Leone and maintained a dedicated Outreach Section, staffed by Sierra Leonean nationals. ${ }^{104}$ Empirical evidence suggests that a significant portion of Sierra Leone's population was aware of the SCSL and believed that it contributed to domestic peace. $^{105}$

The SCSL, however, was created at the request of Sierra Leone's government. When intervening over government objection, the ICC may face government-imposed obstacles. As this Article shows in its Section III case study, State leaders can use their power to impede the ICC's ability to access their domestic audience. Though

100. Peskin, supra note 25, at 954-955.

101. See generally, Daniel Balliet, Communication and Cooperation in Social Dilemmas: A Meta-Analytic Review, 54 J. CONFLICT RESOL. 39, 46-48 (2009) (referencing studies showing that face-to-face, rather than written, communications enhanced cooperation in a broad range of social dilemmas, one reason being that it allowed the participants to more accurately and effectively address concerns); Mina Chang, Why Face-To-Face Meetings Are So Important, FORBES (Feb. 20, 2015), https://www.forbes.com/sites/ellevate /2015/02/20/why-face-to-face-meetings-are-so-important/\#25b858a6aee9

[https://perma.cc/WMX6-HBWK] (noting how face-to-face meetings can help to build trust and understanding).

102. Peskin, supra note 25 , at $954-55$.

103. Clark, supra note 93, at 106 (quoting a conversation with former ICTY Deputy Prosecutor David Tolbert).

104. Rachel Kerr \& Jessica Lincoln, King's Coll. London, War Crimes Research Group, The Special Court for Sierra Leone: Outreach, Legacy and Impact 4, 11 (2008).

105. This Article attributes the SCSL's domestic perception legitimacy in part to the SCSL's outreach program. See Allison Smith, NPWJ Survey on the Special Court for Sierra Leone Highlights Wide and Deep Impact of the Court on Ending Impunity and Strengthening the Rule of Law, No PeAcE Without Justice (Oct. 15, 2012), http://www.npwj.org/ICC/NPWJ-Survey-Special-Court-Sierra-Leone-highlights-wide-anddeep-impact-Court-ending-impunity-and [https://perma.cc/89E9-EY2X] (referencing a survey suggesting that a significant portion of the Sierra Leone population was aware of the Special Court and believed that it contributed to peace in the country, which the author attributes in part to the Outreach Program). 
ICC personnel can travel to States in which documents and witnesses are located, ${ }^{106}$ they do not enjoy unfettered access to places or people. Indeed, the Rome Statute does not obligate States Parties to provide any access to ICC personnel for general outreach efforts. Without in-person access to the domestic populace, the ICC may not be able to replicate the SCSL's outreach success.

If access for ICC personnel is limited, civil society organizations could aid the ICC in its outreach efforts. NGO-developed radio documentaries and traveling plays had a great impact on Rwandan's understanding of post-genocide reconciliation issues. ${ }^{107}$ Though helpful, civil society organizations will not always be able to conduct in-person outreach. Many governments do not allow civil society organizations to operate freely and have implemented measures to stifle or silence NGOs. ${ }^{108}$ This means that in-person outreach efforts by NGOs - like those in Rwanda - may not be an option for the ICC.

Conducting in-person outreach, like sitting regionally, could be costly and may require States Parties to increase the ICC's budget. Still, in-person outreach, whether through the Outreach Section or civil society organizations, seems necessary for reaching information-poor groups and staving off the circulation of disinformation.

\section{The Populace's Other Opportunities for Awareness and Understanding}

Even without in-person outreach, domestic audiences may have opportunities to learn about an institution. As suggested in the previous subsection, it is unlikely that the ICC's target populations will be able to take full advantage of these opportunities and learn enough about how the ICC operates to feel connected with the Court.

Although the ICC maintains a website with documents and other information, few people in the States where the ICC intervenes

106. Rome Statute, supra note 1, art. 93.

107. Marie-Chantal Kalisa, Theatre and the Rwandan Genocide, 18 PEACE REV.: A J. OF Soc. Just. 515, 515-516 (2006).

108. See, e.g., Priyanka Boghani, Putin's Legal Crackdown on Civil Society, PBS (Jan. 13, 2015), http://www.pbs.org/wgbh/frontline/article/putins-legal-crackdown-on-civilsociety/ [https://perma.cc/PGJ2-BNHR] (discussing the 2012 "foreign agent law," signed by Russian President Vladimir Putin, requiring NGOs receiving funding from outside Russia to register as "foreign agents" and be subject to mandatory audits); Laetitia Bader, Civil Society Crackdown in Ethiopia, Human Rights WATCH (Jan. 4, 2013), https://www.hrw.org/news/2013/01/04/civil-society-crackdown-ethiopia [https://perma.cc/42DW-TQZX] (discussing laws passed by the ruling party in Ethiopia attacking civil society, making human rights work in the country almost impossible). 
are likely to seek out and rely on these sources. Much of the world, and particularly individuals in the poorest nations, lack regular internet access. ${ }^{109}$ Illiteracy may be high among populations that have been affected by mass atrocities. ${ }^{110}$ Even if domestic populations are literate, they may not read one of the languages in which the ICC makes information available: English and French.

With limited convenient and accessible ways to learn about the Court from ICC-issued materials, domestic audiences may instead obtain information from their local media. Survey research shows that the vast majority of Bosnians and Croatians never visited the ICTY's website; instead, those domestic audiences learned about the ICTY through television and radio programs. ${ }^{111}$ While convenient sources of information, some journalists not only have personal biases but also may provide selective or false information. ${ }^{112}$ In some States, government leaders control the press. ${ }^{113}$ Leaders can use

109. See Billions of People in Developing World Still Without Internet Access, UN NEwS CENTRE (Sept. 21, 2015), http://www.un.org/apps/news/story .asp?NewsID=51924\#.WN6ccBLyvVo [https://perma.cc/NL3C-UY6U] (reporting that 57 percent of the world's populace, and over 90 percent of people in the poorest countries, are without broadband internet); Michael Pizzi, Survey: 54\% in Developing World Use Internet, AL JAZEERA (Feb. 22, 2016), http://america.aljazeera.com/articles/2016/2/22/study-54percent-in-developing-world-use-internet.html [https://perma.cc/T5XU-GJQB] (stating that while almost half of those living in developing nations have at least occasional access to the internet, amongst the poorest countries, internet usage rates are below 20\%).

110. See, e.g., Kerr \& Lincoln, supra note 104, at 12 (stating that illiteracy rate in Sierra Leone, where the Special Court of Sierra Leone was located, is between 70-80\%). Data from UNICEF indicates that literacy rates for the least developed countries in the world average about $60 \%$. See Literacy, UNICEF DATA, https://data.unicef.org/topic/education/literacy/ (last updated Apr. 2016) [https://perma.cc/F57Q-KDNG].

111. See Marko Milanovic, Establishing the Facts About Mass Atrocities: Accounting for the Failure of the ICTY to Persuade Target Audiences, 47 GEO. J. INT'L L. 1321, 1332 (2016).

112. Id. at $1331 \mathrm{n}$. 30 (citing a survey that found that $27 \%$ of Croatians believed local media sources reported subjectively on ICTY proceedings).

113. See, e.g., Jill Dougherty, How the Media Became One of Putin's Most Powerful Weapons, THE ATLANTIC (Apr. 21, 2015), https://www.theatlantic.com/international/archive /2015/04/how-the-media-became-putins-most-powerful-weapon/391062/

[https://perma.cc/AK8T-YLSC] (stating that in Russia, President Putin has put "not only state media but privately owned broadcast media under the Kremlin's influence," controlling the information citizens receive from television, news, radio, and even the internet); Sabrina Martin, Venezuelan Army Enlisted to Crack Down on Independent Media, PANAM Post (Feb. 28, 2017), https://panampost.com/sabrina-martin/2017/02/28/venezuelan-armyenlisted-to-crack-down-on-independent-media/ [https://perma.cc/8CED-KM9V] (discussing the Venezuelan government's plan to increase censorship of the media); Charlotte Alfred, Watch These Fearless Ugandan Journalists Broadcast Their Own Arrests, THE HufFIngTON Post (Mar. 1, 2016), http://www.huffingtonpost.com/entry/uganda-media- 
that control to ensure that the local media only issues negative reports and commentaries about the ICC.

In addition to using the media to inundate the public with disinformation, government leaders can use their access advantage to directly address the public. They can address the public wherever and as frequently as they wish. Moreover, government leaders share a culture $^{114}$ with their domestic audience and thus face few or none of the cross-cultural barriers to communication ${ }^{115}$ that may affect ICC attempts to build domestic perception legitimacy. ${ }^{116}$ Leaders have the power not only to launch propaganda campaigns against the ICC, but also the ability to message in a way that resonates with the public.

No doubt, the ICC can and should use a range of methods to help domestic audiences understand its purpose, functions, and processes. Remote communications and campaigns, though, are not a complete substitute for in-person outreach. As discussed, with faceto-face communication, ICC personnel have a better chance of making a connection with domestic audiences and persuading them to trust the Court.

crackdown_us_56d5d6f5e4b0bf0dab33808c [https://perma.cc/45FL-88ZU] (discussing the Ugandan government's crackdown on the media after disputed election results wherein $\mathrm{Mu}-$ seveni again assumed the presidency).

114. Culture refers to "the collective programming of the mind that distinguishes the members of one group or category of people from others." See Geert Hofstede, Dimensionalizing Cultures: The Hofstede Model in Context, OnLine ReAdings IN Psychol. \& CULTURE, 3(2011), http://scholarworks.gvsu.edu/cgi/viewcontent.cgi?article=1014\& context=orpc. Culture serves "as a framework for an individual's actions, thoughts, and communication patterns," controlling behavior in deep and unconscious ways." Stephen Michael Croucher et al.,, Argumentativeness and Political Participation: A Cross-Cultural Analysis in the United States and Turkey, 64 CoMm. STUD. 18, 20 (2013).

115. The literature points to the difficulties of cross-cultural communication. See, e.g., Hillary Anger Elfenbein \& Nalini Ambady, Universals and Cultural Differences in Recognizing Emotions, 12 CuRRENT DiReCTIONS PSYCHOL. SCI. 159, 161 (2003) (noting that one barrier to cross-cultural communication is that persons of the same culture are "generally more accurate in recognizing emotions expressed by members of their own culture than in recognizing emotions expressed by members of a different cultural group"); Nancy J. Adler \& John L. Graham, Cross-Cultural Interaction: The International Comparison Fallacy?, 20 J. INT'L BUS. STUD. 515, 517 (1989) (citing to research showing that when cultural differences between individuals are great, barriers to communication and misunderstandings are more likely).

116. See Julie Spencer-Rodgers \& Timothy McGovern, Attitudes Toward the Culturally Different: The Role of Intercultural Communication Barriers, Affective Responses, Consensual Stereotypes, and Perceived Threat, 26 InT'L J. InTERCUltural Rel. 609, 611 (2002) (referencing research). 


\section{The Degree to Which the Populace Trusts its Own Courts}

When domestic audiences have little direct experience with, or significant knowledge about, an international court, they use domestic courts as a proxy for judging the international court's legitimacy. ${ }^{117}$ Individuals who trust national courts are more likely to trust unfamiliar international courts. ${ }^{118}$ As a corollary, individuals who distrust domestic courts transfer those negative feelings when forming opinions about international courts. To illustrate, within the European Union, "countries where fewer people trust their national judiciaries are also countries in which fewer people express trust in the [European Court of Justice]."119

This phenomenon strains the ability of the ICC to achieve domestic perception legitimacy. Because the ICC is a remote, foreign judicial institution, domestic audiences may have little actual knowledge about the Court before it intervenes. Furthermore, domestic audiences in States where the ICC intervenes may not trust their national justice systems. After all, the ICC brings cases only as a last resort, when the State has taken no steps to prosecute, or is unwilling or unable to prosecute, those responsible for mass atrocities. ${ }^{120}$ States meeting that threshold, whether because of complicity, corruption, or serious procedural due process defects, likely have weak rule of law. Weak rule of law leads domestic audiences to question the fairness of their justice system. ${ }^{121}$ When the ICC intervenes over government objection, it likely will have to convince the public that it is a different kind of court - one that operates fairly. With a domestic audience already suspicious of justice institutions, in-person outreach becomes even more important.

117. Chaudoin and Chapman make this point about individuals and the ICC. "Prior to an ICC investigation, citizens typically have very little experience with the court. They have little data, precedents or a track record of cases with which to form their beliefs. Diffuse legitimacy may therefore be driven by citizens' perceptions of their national courts." Chaudoin \& Chapman, supra note 70, at 7 (citing to Voeten).

118. See, e.g., Gibson \& Caldeira, supra note 68, at 459 (discussing opinions about the Court of Justice for the European Union); Voeten, supra note 62, at 416 (hypothesizing that "individuals who trust national courts are also more likely to trust international courts").

119. Voeten, supra note 62, at 425.

120. Rome Statute, supra note 1, art. 17 (complementarity provision).

121. See James L. Gibson, Gregory A. Caldeira, \& Vanessa A. Baird, On the Legitimacy of National High Courts, 92 Am. PoL. ScI. Rev. 343, 345 (1998) (citing West Germany as a state where the rule of law was only introduced after WWII and where diffuse support for national courts took about a generation to develop). 


\section{E. Conclusion}

The discussion above demonstrates the difficult road the ICC must travel to achieve domestic perception legitimacy when the Court intervenes over government objection. The ICC is reliant on in-person outreach, but State leaders hostile to the institution have the upper hand in setting domestic discourse: they are proximate actors; they can deny ICC personnel in-person access to the domestic audience; and they can use their access and communication advantages to undermine the ICC's efforts to persuade the public of its credibility and vision. Moreover, domestic audiences may already distrust courts. If ICC personnel cannot meet face-to-face with domestic audiences to address misgivings about the Court, the ICC has little chance of inspiring public mobilization to pressure State compliance with Court requests and orders.

The Kenya case study demonstrates the seriousness of the access and communication disadvantages the ICC faces when intervening over government objections. The case study also illustrates why States and other supporters of the Court must aid it in its efforts to engender domestic perception legitimacy.

\section{KENYA-AS-ILLUSTRATION: ICC OUTREACH AND THE DOMESTIC NARRATIVE}

\section{A. Introducing the Kenya Case Study}

The Kenyan presidential election of December 27, 2007 precipitated a months-long humanitarian crisis that left over 1,000 dead and an estimated 660,000 displaced. ${ }^{122}$ Under a cloud of suspicion, ${ }^{123}$ the Kenyan electoral commission declared that Mwai Kibaki, the incumbent and the Party of National Unity (PNU) candidate, had won. ${ }^{124}$ Supporters of Raila Odinga, the Orange Democratic Move-

122. AmNeSty InTERnAtional, KenYa: WANing ACCOUNTABILITy FOR JUSTICE AND HUMAN RIGHTS 4 (2015) https://www.amnesty.org/download/Documents/204000/ afr320032014en.pdf [https://perma.cc/376T-LTXN].

123. Third-party, international review of the election shows that the process was, in fact, deeply flawed. See e.g., EU Election Observation Mission, Kenya Final Report on General Elections 27 December 2007 (Apr. 3, 2008) http://www.eods.eu/library/FR\%20KENYA \%2003.04.2008_en.pdf [https://perma.cc/4R99-4QR2]; US Ambassador Michael Ranne-

berger Telex ("we found evidence of rigging on both sides"), http://www.kenyadocex.com/wiki/foia-release-doc-no-c17443900-january-2008/ [https://perma.cc/7EFJ-BXL7].

124. Jeffrey Gettleman, Disputed Vote Plunges Kenya into Bloodshed N.Y. TIMES, Dec. 
ment (ODM) candidate, protested, setting fire to cars and buildings. ${ }^{125}$ The police response, in combination with the response from PNU supporters, led to widespread violence. Because of Kenya's ethnically polarized voting, the violence escalated along ethnic lines. African Union Chairman John Kufuor and former U.N. SecretaryGeneral Kofi Annan were brought in to mediate the crisis, which ended when Kibaki and Odinga signed the National Accord and Reconciliation Act 2008 to create a coalition government. ${ }^{126}$

Though the Kenyan government initially expressed a desire to establish a special tribunal to prosecute persons responsible for the post-election violence, it repeatedly failed to do so. ${ }^{27}$ When it became clear that Kenya was going to allow impunity to reign, the ICC stepped in. On November 26, 2009, the ICC Prosecutor opened a proprio motu investigation regarding the post-election violence. ${ }^{128}$ The Court authorized the investigation on March 31, 2010, noting the "inactivity on the part of the Kenyan authorities to address the potential responsibility of those who are likely to be the focus of the Court's investigation." "129 By the end of the year, the ICC Prosecutor had brought crimes against humanity charges against five high-level Kenyan government officials and one prominent journalist. ${ }^{30}$ The ICC Prosecutor alleged that William Ruto, ${ }^{131}$ Henry Kosgey, ${ }^{132}$ and Joshua arap Sang ${ }^{133}$ had orchestrated violence against PNU members after the election results were announced. He further alleged that

31,2007 at $\mathrm{A} 1$

125. Id.; Scores Dead in Kenya Poll Clashes, BBC (Dec. 31, 2007), http://news.bbc.co.uk/2/hi/africa/7165602.stm [https://perma.cc/BMF5-M4JG].

126. Monica Kathina Juma, African Mediation of the Kenyan post-2007 Election Crisis, 27 J. CONTEMP. AFr. STUD. 407, 412-13 (2009).

127. How Kenya Handled Local Tribunal Process, Daily Nation (Sept. 17, 2013), http://www.nation.co.ke/news/politics/How+Kenya+handled+local+tribunal+process++//1064/1997172/-/iko52x/-/index.html [https://perma.cc/C3GW-MWEN].

128. Pre-Trial Chamber II, Request for Authorisation of an Investigation Pursuant to Article 15, ICC-01/09, https://www.legal-tools.org/uploads/tx_ltpdb/doc785972_06.pdf [https://perma.cc/K2JM-KCSS]

129. Pre-Trial Chamber II, Decision Pursuant to Article 15 of the Rome Statute on the Authorization of an Investigation in the Situation in the Republic of Kenya, ICC-01/09, IIII 54, 184-185 https://www.icc-cpi.int/CourtRecords/CR2010_02399.PDF [https://perma.cc/8JJL-5LBG]

130. See Kenya's Post Election Violence, supra note 22.

131. Then Minister of Higher Education, Science, and Technology and a Member of Parliament. Ruto became Kenya's Deputy President in 2013.

132. Then Minister of Industrialization and a Member of Parliament.

133. Then Head of Operations of KASS FM, a prominent news radio station. 
Uhuru Kenyatta, ${ }^{134}$ Francis Muthaura, ${ }^{135}$ and Mohammad $A 1 i^{136}$ had responded to the attacks on PNU members by developing and executing a plan to attack ODM supporters. ${ }^{137}$

Though the ICC's Pre-Trial Chamber refused to confirm charges against Kosgey and Ali, the OTP actively prosecuted four of the Kenya cases for several years. ${ }^{138}$ The ICC Prosecutor maintained charges against Mathaura and Kenyatta until 2013 and 2014, respectively. ${ }^{139}$ The cases against Ruto and Sang were vacated in $2016 .{ }^{140}$

134. Then Deputy Prime Minister and Head of Finance. Kenyatta became Kenya's President in 2013.

135. Then Head of the Public Service and Secretary to the Cabinet and Chairman of the National Security Advisory Committee.

136. Then Chief Executive of the Postal Corporation of Kenya and a former Commissioner of the Kenyan Police.

137. See Prosecutor v. Ruto, Case No. ICC-01/09-01/11, Prosecutor's Application Pursuant to Article 58 as to William Samoei Ruto, Henry Kiprono Kosgey and Joshua Arap Sang, III 4-6 (Dec. 15, 2010), http://www.icc-cpi.int/iccdocs/doc/doc1367853.pdf [https://perma.cc/9A6F-4JW3]. In January 2012, the ICC's Pre-Trial Chamber refused to confirm charges against Kosgey and Ali, concluding that the prosecutor had not met the necessary evidentiary threshold for proceeding. See Pre-Trial Chamber II, Request for Authorisation of an Investigation Pursuant to Article 15, supra note 128, at 110, 138; Pre-Trial Chamber II, Decision Pursuant to Article 15 of the Rome Statute on the Authorization of an Investigation in the Situation in the Republic of Kenya, supra note 129, at 152; Tom Maliti, ICC Confirms Charges Against Four Out of Six Kenyan Suspects, INT'L JuST. Monitor (Jan. 23, 2012) http://www.ijmonitor.org/2012/01/icc-confirms-charges-against-four-out-of-sixkenyan-suspects/ [https://perma.cc/KRR6-H564].

138. Few ICC cases have actually proceeded to a trial against suspects who have appeared in The Hague. Excluding the Kenyan defendants and persons prosecuted for "administration of justice offenses," the suspects the ICC has brought to trial as of March 2017 include Ahmad Al Faqi Al Mahdi (Mali), Jean-Pierre Bemba Gombo (CAR), Germain Katanga (DRC), Charles Blé Goudé (Ivory Coast), Laurent Gbagbo (Ivory Coast), Thomas Lubanga Dyilo (DRC), Mathieu Ngudjolo Chui (DRC), Bosco Ntaganda (DRC), and Dominic Ongwen (Uganda). See Defendants, INT'L CRIM. CT., https://www.icccpi.int/Pages/cases.aspx (last visited Nov. 5, 2017) [https://perma.cc/WMT2-2H2T]. Each of the situations in Mali, the CAR, the DRC, and Uganda involved self-referrals. See Situations under Investigation, , INT'L CRIM. CT., https://www.icc-cpi.int/pages/situations.aspx (last visited Nov. 5, 2017) [https://perma.cc/QH2S-TWK2].

139. See Luis Moreno Ocampo, Int'l Crim. Ct. Prosecutor, Int'l Crim. Ct., Statement by ICC Prosecutor on the Notice to Withdraw Charges Against Mr Muthaura (Mar. 11, 2013), https://www.icc-cpi.int/legalAidConsultations?name=OTP-statement-11-03-2013

[https://perma.cc/RGQ2-H84M]; Fatou Bensouda, Int'1 Crim. Ct. Prosecutor, Int'1 Crim. Ct., Statement of the Prosecutor of the International Criminal Court, Fatou Bensouda, on the withdrawal of charges against Mr. Uhuru Muigai Kenyatta (Dec. 5, 2014), https://www.icccpi.int/legalAidConsultations?name=otp-statement-05-12-2014-2 [https://perma.cc/67NZ477T].

140. Marlise Simons and Jeffrey Gettleman, International Criminal Court Drops Case 
In each of the four cases, charges were withdrawn because of issues relating to witness tampering and State obstruction of the ICC Prosecutor's efforts to gather evidence. On September 19, 2016, the Court issued a finding of Kenyan noncompliance in the Kenyatta case and referred the matter to the Assembly of States Parties. These outcomes suggest that the ICC did not build enough domestic perception legitimacy to induce the public to pressure government officials into compliance.

This Article focuses on the Kenya cases because the Kenyan situation was not self-referred. Kenya evidenced no intention of aiding and supporting the ICC in its efforts to develop evidence to prosecute the accused. Instead, Kenya objected to and fought the ICC's intervention. ${ }^{141}$ Using the Kenya cases, this Article explores whether and to what extent government leaders used their access and communication advantages to negatively influence public perception of the ICC. Importantly, the Kenya cases were active for several years. With active cases, the ICC has the greatest need for compliance and thus the greatest incentive to build domestic perception legitimacy through public engagement. This Article searches the multi-year record for evidence of ICC outreach efforts and countervailing State action.

In addition to drawing on documentary evidence, this Article draws on interviews conducted during 2015 and 2016 with Kenyan elites, as well as employees of the ICC Office of the Prosecutor. ${ }^{142}$

Against Kenya's William Ruto, N.Y. Times (Apr. 5, 2016), http://www.nytimes.com/2016/04/06/world/africa/william-ruto-kenya-icc.html?_r=0 [https://perma.cc/99FC-F6UU] (referencing the vacated cases); Tom Maliti, Appeals Chamber Reverses Decision on Witness Statements, INT'L JUST. MONITOR (Feb. 12, 2016), http://www.ijmonitor.org/2016/02/appeals-chamber-reverses-decision-on-witnessstatements/ [https://perma.cc/7LGQ-DJH2] (referencing the Appeals Chamber decision).

141. See, e.g., Nicholas Kulish, Kenyan Lawmakers Vote to Leave International Court, N.Y. Times (Sept. 5, 2013), http://www.nytimes.com/2013/09/06/world/africa/kenyanlawmakers-vote-to-leave-international-court.html?pagewanted=all\&amp;_r=0 [

https://perma.cc/A2DS-6MX2](quoting the majority leader in the Kenyan National Assembly as saying, "[t]he sovereign state of Kenya, with a functioning judiciary, with a vibrant democracy, one of the best democracies in Africa, is under threat.").

142. The Author, aided by colleagues, conducted interviews with twenty five Kenyan former government officials, media persons, academics, and leaders in civil society and think tanks. The Kenyan interviewees varied in political and ethnic affiliation. These interviews were conducted in Nairobi during summer and fall 2015. Additional interviews of current and former ICC personnel were conducted during summer 2016. The interviews with Kenyan elites were done as part of a project being funded by The Hague Institute for Global Justice (The Hague Institute) entitled, "The Peace-Justice Nexus: The Potential Impact of the ICC on Conflict, Mass Atrocities, and Human Rights Violations." Two researchers from The Hague Institute, Eamon Aloyo and Tessa Alleblas, participated in the Kenya interviews, as 
NPI-Africa, a local civil society organization with extensive experience working on peace and conflict transformation in Kenya, ${ }_{143}$ organized interviews with persons knowledgeable about Kenya's interactions with the ICC. The Author organized interviews with current and former ICC personnel. In presenting perspectives from both Kenyans and ICC personnel, this Article hopes to provide robust and informative qualitative data on domestic perception legitimacy.

\section{B. Evidence from Kenya}

The data show that the Kenyan government played a role in impeding the ICC's conduct of in-person public outreach. Government officials made ICC personnel feel unsafe in Kenya and failed to protect them from third-party threats. The government encouraged public apprehension of speaking with ICC personnel. Further, the government stymied the efforts of civil society organizations that could have aided the ICC in conducting in-person outreach. These setbacks were exacerbated by the ICC's budget and resources limitations.

The data also show that Kenyan leaders were able to communicate effectively with the public to besmirch the reputation of the ICC. Kenyatta and Ruto, elected President and Deputy President in March 2013, repeatedly accused the Court of being a colonialist institution biased against Africa and infringing on Kenya's sovereignty. They waged a disinformation campaign to frustrate ICC efforts to raise awareness and understanding of ICC functions and processes. As discussed below, the government narrative resonated with the public, which grew wary of the Court and the charges brought against domestic leaders.

\section{Raising Awareness and Understanding}

The first three factors, identified above, that bear on domestic perception legitimacy implicate the domestic audience's actual awareness and understanding of an international institution. When an international court sits regionally, it creates avenues for in-person

well as the interviews with ICC personnel. In Kenya, Nahashon Kariuiki from NPI-Africa also participated in several interviews. Because of the sensitivity of the topics addressed during the interviews, interviewees were promised that their identities would not be revealed in any reports or publications.

143. For more information about NPI-Africa, see NPI AFRICA, http://www.npiafrica.org/ [https://perma.cc/3NMS-EV78] (last visited Nov. 5, 2017). 
participation in its proceedings. When an international court or its civil society allies engage in in-person outreach, they actively engage members of the domestic audience, who learn about the court and its functions. Finally, when an international court produces written outreach materials or radio programs, it strives to explain its functions and goals to the domestic audience.

When an international court fails to raise awareness and understanding, it does nothing to dispel the domestic audience's likely preconceptions of the international court's ability to operate fairly and deliver just outcomes. Moreover, failure to raise awareness and understanding leaves the international court vulnerable to attacks and disinformation spread by hostile parties.

\section{a. ICC Outreach}

The ICC Outreach Section's in-person efforts in Kenya were limited. One interviewee, a Kenyan civil society leader, suggested that the ICC Field Outreach Coordinator visited Kenya fewer than five times during the investigations and prosecutions. ${ }^{144}$ The Outreach Coordinator allegedly spent most her time in Eldoret, a major urban center, and with Kenyan elites - rather than in village settings or with members of the general public. ${ }^{145}$ Leadership at Mawingu Camp, which housed more than 1,000 internally-displaced families, reported that the families were "waiting to see [ICC] officials and talk to them, but none have been here so far." "146 The only visitors to Mawingu Camp were politicians, coming to "demonise the ICC."147

These accounts are consistent with the ICC's annual outreach reports. ${ }^{148}$ The 2010 Outreach Report shows that when ICC personnel held in-person meetings, they addressed community leaders, civil society, media, and university faculty. ${ }^{149}$ Ordinary members of the public were generally expected to learn about the ICC through print-

\footnotetext{
144. Interview with Subject 963.

145. Id.

146. Kenya Accused of Hampering ICC Outreach, INST. FOR WAR \& PEACE REPORTING (Dec. 7, 2011), https://iwpr.net/global-voices/kenya-accused-hampering-icc-outreach [http://perma.cc/DGT9-ARVD].

147. Id.

148. Interacting with communities, supra note 96 (showing that the ICC's website contains Outreach Reports from only 2009 and 2010).

149. Int'l Crim. Ct., Outreach Unit, Outreach Report 2010, at 69 (2010), https://www.icc-cpi.int/iccdocs/PIDS/publications/OUR2010Eng.pdf [http://perma.cc/752CE43D] [hereinafter Outreach Report 2010].
} 
ed materials, radio programming, ${ }^{150}$ and a twelve-episode television show called Ask the Court. ${ }^{151}$

Security concerns drove, at least in part, the ICC's decision to conduct minimal in-person outreach. The ICC's 2010 Outreach Report states that the ICC would continue to pursue direct outreach with "opinion leaders" but that "security issues" prevented ICC personnel from reaching many communities directly. ${ }^{152}$ The outreach plan for 2011 referenced the possibility of running town halls, "pending security assessment." 153

Several interviewees who currently or formerly worked for the ICC conveyed that ICC personnel felt unsafe traveling within Kenya. One interviewee said "everybody has an accident" in Kenya. ${ }^{154}$ That interviewee went on to say that it did not seem that OTP folks were able to get anywhere within Kenya. ${ }^{155}$ Another interviewee said that investigating in Kenya was difficult because the investigators were being followed. ${ }^{156}$ That interviewee believed that ICC personnel and their communications were being surveilled. ${ }^{157}$

Members of the public, too, feared or were made to feel unsafe for affiliating with the ICC. Local news reported that individuals with information against the Kenyan suspects were threatened or killed. ${ }^{158}$ ICC witnesses refused to testify at trial, claiming that they

150. Id. at 72. See also Press Release, Int'l Crim. Ct., The ICC launches Outreach Programme radio campaign in Kenya, (March 12, 2010), https://www.icccpi.int/Pages/item.aspx ?name=pr606\&ln=fr [https://perma.cc/EXG5-YKSA] (announcing the ICC's launch of its radio campaign in Kenya in March 2010 designed to inform the general population about the ICC's work and the Kenya cases).

151. Each episode would run for roughly ten minutes and would involve some number of ICC officials answering questions, often technical in nature. Though the ICC has not published its estimated viewership for the program, most episodes available on YouTube have fewer than 1,000 views. LIONEL NichOls, THE INTERNATIONAL CRIMINAL COURT AND THE END OF IMPUNITY IN KENYA 79 (2015); see also IntlCriminalCourt, YouTuBE, https://www.youtube.com/user/IntlCriminalCourt/search?query=ask+the+court+kenya (last visited Nov. 5, 2017).

152. 2010 Outreach Report, supra note 149, at 78.

153. Id. at 108 .

154. See Interview with Subject 101.

155. Id.

156. See Interview with Subject 102.

157. Id.

158. See, e.g., Barnabas Bii \& Dennis Lubanga, Missing 'ICC Witness' Found Dead in River, DAILY NATION (Jan. 4, 2015), http://www.nation.co.ke/news/ICC-witness-founddead-in-Eldoret/-/1056/2578254/-/7jbtne/-/index.html [https://perma.cc/68U2-6VA6] (reporting on an ICC witness found dead in a river); see also Walter Menya, Shocking: Uhuru 'Killed' All Mungiki Witnesses Says ICC Prosecutor Bensouda, KENYA ToDAY (Aug. 2, 
had received threats and were worried that their families would suffer retaliation. ${ }^{159}$ Several interviewees reported that members of the public believed they would face physical harm if they spoke with ICC personnel. ${ }^{160}$ One interviewee intimated that the 2013 election exacerbated Kenyans' concerns; Kenyatta, empowered as President, "could do these sorts of things" to Kenyans supporting the ICC. ${ }^{161}$ By interfering with witnesses ${ }^{162}$ or failing to protect them, ${ }^{163}$ the

2014), http://www.kenya-today.com/news/uhuru-kenyatta-killed-mungiki-witnesses-saysicc-prosecutor-bensouda [https://perma.cc/G6E6-KYUH] (stating that the ICC prosecutor alleged that Kenyatta caused gang witnesses against him to be killed); Caspar Waithaka \& John Ngirachu, Mungiki Leader Killed in Nairobi, Daily Nation (Nov. 5, 2009), http://www.nation.co.ke/news/-/1056/682504/-/4cjm1fz/-/index.html

[https://perma.cc/JQ8V-GUGA] (stating that another gang leader was found killed on the same day the OTP requested permission to open an investigation into the Kenyan situation).

159. See Further Threats to ICC's Kenya Witnesses, Inst. WAR \& PEACE REPORTING (Aug. 29, 2013), https://iwpr.net/global-voices/further-threats-iccs-kenya-witnesses [https://perma.cc/Z89P-5FC7] (referencing witnesses backing out of the Ruto/Sang trials because of threats and reporting on other witnesses); see also Susanne D. Mueller, Kenya and the International Criminal Court (ICC): Politics, the Election and the Law, 8 J. E. AFR. STUD. 25, 33 (2013) (referencing a plan by the ICC defendants and their supporters "to eliminate, intimidate, and bribe people who knew too much about the PEV, key individuals who were part of it, and civil society activists who were assisting and sheltering potential witnesses.").

160. See, e.g., Interview with Subject 333 (stating that in some village settings people are afraid to speak about the ICC and also that because there have been problems with ICC witnesses disappearing, we may find that some people in Kenya would not want to speak with us about our project); Interview with Subject 444 (stating that people in some areas do not trust the ICC or they also believe that persons who talk to the ICC face some danger as being perceived as witnesses and that witnesses for the ICC have allegedly been threatened and killed); Interview with Subject 568 (stating that that people in Kenya really do believe that Kenyatta and Ruto had witnesses threatened or killed and suggesting that no rational witness would believe that he would be safe if he went against the president); Interview with Subject 582 (informing the Author to emphasize her connections with NPI-Africa and to distance herself from the ICC in future interviews, such that interviewees would know that speaking with her would not result in any harm or government retribution).

161. Interview with Subject 444 (suggesting that Kenyans believed that Kenyatta played a role in intimidating ICC witnesses or causing their disappearance); see also Interview with Subject 568 (stating that Kenyans believed Kenyatta and Ruto caused ICC witnesses to be threatened or killed).

162. In 2015, the ICC Prosecutor revealed that it had tapes of conversations indicating Ruto's agents were bribing and intimidating witnesses Judie Kaberia, Prosecution Says It Has Evidence of Ruto ICC Witness Bribery, CAPITAL News (Jun. 25, 2015), http://www.capitalfm.co.ke/news/2015/06/prosecution-says-it-has-evidence-of-ruto-iccwitness-bribery/ [https://perma.cc/M6P9-XEYM]; Prosecutor v. Ruto, Case No. ICC-01/0901/11, Decision on Prosecution Request for Admission of Prior Recorded Testimony, TII 54, 60 (Aug. 19, 2015), https://www.icc-cpi.int/CourtRecords/CR2015_15400.PDF [https://perma.cc/8S8N-58VQ]. 
Kenyan government created an atmosphere of fear and undermined the ICC's access to the general public. ${ }^{164}$

Beyond this atmosphere of fear, Kenyan cultural norms limited the ICC's ability to conduct in-person outreach. Outsiders are not easily welcomed into villages. Without receiving approval from a village chief or paying meeting attendees a "sitting allowance," ICC personnel would have had difficulties filling a town hall. ${ }^{165}$ Kenyan leaders, perhaps unsurprisingly, did not use their power to encourage members of the public to meet and cooperate with the ICC.

Budgetary issues, exacerbated by security concerns and ICC personnel's outsider-status, restricted the ICC's capacity to engage in-person outreach to ordinary citizens. The ICC had an outreach budget of $\$ 910,000$ (USD) for 2009. ${ }^{166}$ The Head of the ICC Outreach Section suggested that this would only permit "very limited outreach." 167 One interviewee, affiliated with the ICC, lamented that the ICC's entire budget was "very small-less than Amnesty International's." 168 The ICC did not have the funds to staff field offices or repeatedly send ICC personnel throughout Kenya to meet with members of the public.

With limited in-person outreach, the ICC was not able to create the awareness and understanding necessary to build domestic perception legitimacy. One interviewee, a civil society actor, suggested that the ICC's mass media communications were ineffective because many Kenyans get their information "by word of mouth" or directly from an "ethnic lord" or community leader. ${ }^{169}$ Other civil society representatives complained that victims of Kenya's post-election vio-

163. See, e.g., Statement by ICC Prosecutor on the Notice to Withdraw Charges Against Mr. Muthaura, supra note 139; see also Statement of the Prosecutor of the International Criminal Court, Fatou Bensouda, supra note 139.

164. The Author's own experience in Kenya during 2015 (while the case against Ruto was still pending) is consistent with these reports indicating that citizens were frightened of being seen speaking with "the ICC." Some persons we contacted did not wish to speak about the ICC and the cases. Others were willing to speak, but only after we assured them that we were not in any way associated with the ICC and that we would not identify them by name in any publications.

165. See Interview with Subject 963.

166. See ICC Seen as Struggling to Communicate, Special Report, InST. WAR \& PEACE REPORTING (July 14, 2009), https://iwpr.net/global-voices/icc-seen-struggling-communicate [https://perma.cc/D47B-CSGT].

167. Id.

168. See Interview with Subject 103.

169. See Interview with Subject 444. 
lence were unsatisfied with the ICC's limited outreach. ${ }^{170}$ Overall, many victims of the post-election violence lacked sufficient information to register as victim participants. ${ }^{171}$ Poor communication led victims to have unrealistic expectations about what the ICC could achieve in Kenya - resulting in victims becoming dissatisfied with the Court's progress. ${ }^{172}$ It comes as no surprise that the public did not mobilize on behalf of the ICC when the public in "some parts of Kenya that bore the brunt of the violence" was "barely aware" of the Court. $^{173}$

\section{b. Civil Society's Pro-ICC Outreach}

The literature shows that civil society may be able to fill outreach gaps and hold in-person meetings to increase public awareness and understanding of international institutions. Many Kenyan civil society organizations backed the ICC. ${ }^{174}$ Some even lent their knowledge and assistance to the ICC Prosecutor, helping to develop contact on the ground with victims and witnesses. ${ }^{175}$ However, the civil society organizations assisting the ICC made enemies of Kenyatta and Ruto, and the two fought back. The government used its power to impede pro-ICC civil society organizations' access to domestic audiences.

One government strategy involved rhetoric labeling civil so-

170. The report relied on interviews with civil society representatives and other elites because the "security situation" made it impossible to interview victims directly. See Thomas Obel Hansen, In the Shadow of Politics: Victim Participation in the Kenyan ICC Cases, June 2016, Impunity Watch, at 7 (Transitional Justice Institute Research Paper No. 16-17, June 2016).

171. Id. at 30, 34 (noting that members of the public were unsure of the differences between registering as a witness and as a victim; concluding that "victims lacked information and were often confused about how to register and the purpose thereof.").

172. Id. at 30 .

173. Kenya Accused of Hampering ICC Outreach, supra note 146.

174. See, e.g., Mueller, supra note 159, at 34 (stating that immediately after the ICC prosecutor sought permission to open the Kenya investigation in 2009, civil society activists in Kenya began complaining of witness intimidation); Thomas Obel Hansen and Chandra Lekha Sririam, Fighting for Justice (and Survival): Kenyan Civil Society Accountability Strategies and Their Enemies, 9 INT'L J. OF TRANS JUST. 1, 6 (2015) (referencing a group of civil society organizations within Kenya that began calling for justice and accountability after the post-election violence); Simon Allison, Think Again: Civil society in Kenya is down, but not out, Inst. for Security Stud. (Jan. 5, 2016), https://issafrica.org/iss-today/think-againcivil-society-in-kenya-is-down-but-not-out [https://perma.cc/F673-6646] (referencing civil society's calls for Kenya to comply with its obligations under the Rome Statute).

175. See Hansen and Sririam, supra note 174, at 9-10. 
ciety organizations as pawns of foreigners. ${ }^{176}$ Kenyatta and Ruto advanced this rhetoric after civil society organizations brought suit, arguing that the pair was precluded from running for office by the pending ICC charges. ${ }^{177}$ The defense strategy, in fact, was to blame the West. One interviewee explained that the two leaders argued that the "Western Imperialists" were behind the lawsuit to keep them from running for office. ${ }^{178}$ After successfully defeating that challenge, Kenyatta and Ruto stepped up their offensive against civil society. Both while campaigning and after taking office, Kenyatta and Ruto countered civil society's narrative of accountability by calling civil society tools of western imperialism, anti-Kenyan, and even "evil society." their ICC cases, claiming that human rights activists in Kenya received backing from foreign donors and thus coached ICC witnesses to lie. ${ }^{180}$

Not unlike the interviewed ICC personnel, several civil society organizations reported that government officials illegally entered

176. See Kenya: Rights Defenders Under Attack, Human RighTS WATCH (Oct. 10, 2013), https://www.hrw.org/news/2013/10/04/kenya-rights-defenders-under-attack [https://perma.cc/ZL3V-MA3R].

177. Jeffrey Gettleman, Kenyan Court Rejects Suit Against Presidential Candidate, N.Y. TiMES (Feb. 15, 2013), http://www.nytimes.com/2013/02/16/world/africa/kenyancourt-rejects-suit-against-kenyattas-candidacy.html.

178. Interview with Subject 444.

179. See Hansen and Sriram, supra note 170, at 15 (discussing the government's counter-narrative painting the ICC and civil society organizations as tools of Western imperialism); Christian M. De Vos, All roads lead to Rome: Implementation and domestic politics in Kenya and Uganda, in Contested Justice: The Politics AND PRACTICE OF InTERnATIONAL Criminal Court Interventions 379, 402 (Christian De Vos, Sara Kendall \& Carsten Stahn eds., 2015) (noting that during their presidential campaign, Kenyatta and Ruto labeled civil society as the "evil society" for allegedly conspiring against Kenya and its people by supporting the ICC cases); Njonjo Mue, The ICC mustn't give up in Kenya, OPEN DEMOCRACY (Nov. 6, 2014), https://www.opendemocracy.net/openglobalrights/njonjomue/icc-mustn\%E2\%80\%99t-give-up-in-kenya [https://perma.cc/X2CJ-J69U] (stating that after Kenyatta and Ruto took office, their supporters viciously attacked civil society calling them "evil society" and agents of foreign powers); Allison, supra note 174(stating that the Kenyatta government is working to turn the public against civil society, advancing the narrative that they are working to turn the public against civil society, calling the organizations unpatriotic because they go to the West for money and alleging that they use that money to support terrorist and criminal activity).

180. See Walter Menya, State targeting us over support for Hague cases, civil society protests, DAILY NATION (Oct. 24, 2014), http://www.nation.co.ke/news/politics/CivilSociety-ICC-Hague-Cases-Jubilee-Government/-/1064/2499628/-/kylkb4z/-/index.html [https://perma.cc/Y62Q-P9YC]. 
or bugged their offices. ${ }^{181}$ Government officials directly threatened, even in public settings, ${ }^{182}$ civil society representatives who were supporting the ICC. This atmosphere of government intimidation caused some organizations to scale back their ICC-related activities to protect themselves from their own government. ${ }^{183}$ One interviewee asserted that the government backlash had a chilling effect, and activists, "afraid," ceased being as vocal as they once were. ${ }^{184}$

The Kenyan government, once under Kenyatta and Ruto, used more than rhetoric and intimidation to silence pro-ICC civil society organizations. After the 2013 election, Kenya's Attorney-General proposed an amendment to the Public Benefits Organisations Act that would put a $15 \%$ cap on foreign funding for NGOs. ${ }^{185}$ The bill was widely criticized, both domestically and internationally. One civil society representative protested that the amendment, if passed, "would make it hard for NGOs in the country to operate as it would cripple their source of funding." 186 The civil society community viewed the amendment as a direct response to civil society support for the ICC. ${ }^{187}$ Three separate United Nations Special Rapporteurs

181. See Hansen and Sririam, supra note 170, at 17.

182. See, e.g., Simon Allison, How can we better protect human rights defenders?, Inst. For Security Stud. (Jan. 3, 2017), https://issafrica.org/iss-today/how-can-we-better-protecthuman-rights-defenders [https://perma.cc/NJ25-FFYC]

183. Hansen and Sririam, supra note 170, at 17.

184. Interview with Subject 822.

185. A Bill for an Act of Parliament to Make Minor Amendments to Statute Law, No. 32 (2013) Kenya Gazette Supplement No. 146 § 123A; see also Hanibal Goitom, Kenya: Rejection of Bill Capping NGO Foreign Funding and Giving Spy Agency Broadened Surveillance Powers, Global Legal Monitor (Library of CONGRess) (Dec. 12, 2013), http://www.loc.gov/law/foreign-news/article/kenya-rejection-of-bill-capping-ngo-foreignfunding-and-giving-spy-agency-broadened-surveillance-powers/ [https://perma.cc/P943V6SE]; The Statute Law (miscellaneous Amendments) Bill, 2013: Why It Is a Bad Law For the Country and Why Kenya's Civil Society Organizations Will Resist It, NAT'L CoALITION OF HUM. RTS.DEFENDERS (Nov. 9, 2013), http://nchrdk.org/the-statute-law-miscellaneousamendments-bill-2013-why-it-is-a-bad-law-for-the-country-and-why-kenyas-civil-societyorganizations-will-resist-it/ [https://perma.cc/R7A4-7WC9]; Maina Kiai, In Kenya, Averting a Move to Strangle Civil Society with the Financial Noose, OPEN DEMOCRACY (Dec. 18, 2013), https://www.opendemocracy.net/openglobalrights/maina-kiai/in-kenya-avertingmove-to-strangle-civil-society-with-financial-noose [https://perma.cc/EJ6Q-8RRA]; Interview with Subject 58.

186. Kenya: Draft Law Limits Foreign Funding for NGOs, HORN AFFAIRS (Nov. 5, 2013), http://hornaffairs.com/2013/11/05/kenya-draft-law-limits-foreign-funding-for-ngos/ [https://perma.cc/TF3Z-S76U].

187. Hisayo Katsui et al., Reducing Inequalities: A Human Rights-based Approach in Finland's Development Cooperation with Special Focus on Gender and Disability: A Case Study on Ethiopia and Kenya 71 (2014) 
condemned the amendment for its "undue State interference" in civil society. ${ }^{188}$ Though the amendment was defeated, ${ }^{189}$ the government subsequently deregistered hundreds of pro-ICC civil society organizations. ${ }^{190}$

Because of government interference, civil society organizations were unsuccessful in their efforts to increase awareness and understanding of the Court through in-person outreach. Civil society's support for the Court led to a government backlash that threatened not just international criminal accountability but also basic civil and political rights in Kenya.

\section{c. Hostile Leaders' Anti-ICC Narrative}

Kenyatta and Ruto used their proximity to the public and their control over local media to attack and impugn the ICC. Taking advantage of the public's lack of awareness of the ICC, Kenyatta, Ruto, and their allies depicted the ICC as a neocolonialist institution biased against Africa and improperly intruding on Kenyan sovereignty. Their narrative, which played off of Kenyan history and identity, resonated with the domestic audience. Ultimately, ordinary Kenyans supported those charged with crimes against humanity-instead of the international institution trying to bring perpetrators to justice.

The Kenyan case illustrates domestic leaders' built-in communication advantage. Domestic leaders typically have greater access to the domestic audience; they can hold local rallies and leverage their relationships with journalists and media organizations.

http://www.abo.fi/fakultet/media/24259/reducinginequalitiesnetversion020414.pdf [https://perma.cc/3WAV-FVQG].

188. Kenya: Statute Law Bill Poses Grave Threat to Civil Society and must be Rejected: UN Rights Experts, United Nations Human Rights: OfFicE OF THE High COMMISSIONER (Dec. 3, 2013), http://newsarchive.ohchr.org/EN/NewsEvents/Pages /DisplayNews.aspx?NewsID=14055\&LangID=E [https://perma.cc/4HJL-AEL4].

189. The Kenyan Parliament voted down the amendment, finding that it was incompatible with the Constitution. Dispatches: Kenya Stifles Media, Restricts Police Oversight, HUM. RTS. WATCH (Dec. 9, 2013), https://www.hrw.org/news/2013/12/09/dispatches-kenyastifles-media-restricts-police-oversight. [https://perma.cc/3XWA-28XU].

190. The government eventually suspended, but did not cancel, deregistrations. This left civil society organizations wondering how long they would continue to exist. See interview with Subject 582; Interview with Subject 822. See also Allison, supra note 174 (stating that the Kenyatta government deregistered "959 NGOs for various reasons, including alleged misappropriation and embezzlement of donor funds, diversion of donor funds, undeclared foreign funding, money laundering and terrorism financing" and that the list included many highly respected organizations). 
Moreover, they speak the same language as the domestic audience. They have the same collective memory and national identity. Domestic leaders, regardless of a State's ethnic fractionalization, can fashion themselves as in-group members vis-à-vis remotely-located foreigners.

\section{i. Reaching and Rallying the Domestic Audience}

The timing of Kenyatta's and Ruto's "anti-ICC" messaging campaign reveals its instrumental nature. Kenyatta and Ruto began impugning the ICC once the ICC released the names of its suspects. In April 2011, after returning from their first appearance in The Hague to answer charges, Kenyatta and Ruto held a prayer rally where they blamed the case on politics and Western meddling. ${ }^{19}$ Thousands attended. ${ }^{192}$ By late 2012, the two political and ethnic rivals ${ }^{193}$ had joined together to create the Jubilee Coalition and capture the State's top leadership positions. ${ }^{194}$

The ICC featured heavily in the campaign narrative. With the help of a British marketing firm, ${ }^{195}$ Kenyatta and Ruto turned the ICC's indictments into an advantage, drumming up populist support by painting themselves as victims of Western imperialism. ${ }^{196}$ Ken-

\begin{tabular}{cccccrr}
\hline 191. David & McKenzie, Kenyans Rally for & Two & Politicians \\
Accused of & Crimes Against Humanity, CNN
\end{tabular}
http://www.cnn.com/2011/WORLD/africa/04/11/kenya.icc/ [https://perma.cc/QY4C-NFH3].

192. Id.

193. Kenyatta is a leader of the Kikuyu community, while Ruto is a leader of the Kalenjin community. The two communities engaged in violence against one another after the 2007 presidential elections. Many have documented the long history of conflict between the two communities. See Thomas P. Wolf, International Justice vs. Public Opinion? The ICC and Ethnic Polarisation in the 2013 Kenyan Election, 12 J. OF AFR. ElECS. 143, 155-56 (2013); Gabrielle Lynch, Electing the 'alliance of the accused': the success of the Jubilee Alliance in Kenya's Rift Valley, 8 J. OF E. Af. STUD. 93, 96-99 (2013).

194. Daniel Waweru, Kenya: The Rise of the "Uhuruto," Afr. ArgumEnTS (Dec. 5, 2012), http://africanarguments.org/2012/12/05/kenya-the-rise-of-the-uhuruto-by-danielwaweru/ [https://perma.cc/2F39-G662].

195. The public either did not know or did not care that Kenyatta and Ruto, who ran on an anti-imperialist, anti-West message, had retained a British marketing firm to develop the campaign message.

196. See Corporate Europe Observatory, Spin Doctors to the Autocrats: How EUROPEAN FIRMS WhITEWASH REPRESSIVE REGIMES 34 (2015) (explaining the role of BTP Advisers in helping to craft and spread the Western imperialism message); Joseph, Did a British PR firm Propagate the Anti-Western Rhetoric Surrounding the ICC Cases?, NeVER AGAIN (March 7, 2013), https://neveragain.co.ke/did-british-pr-firm-propagate-anti-westernrhetoric-surrounding-icc-cases/article (same) [https://perma.cc/6THH-S5AZ]; Nic 
yatta and Ruto railed against the ICC, calling it biased against Africa and a tool of the neocolonialist West meant to "limit the control wielded by Kenya's political elites." $" 197$ In rallies, they asked the public to reject Western imperialism, emphasizing that their electoral victory would serve as a "vote of no confidence in the ICC." "198 One interviewee, a journalist, explained why the media in Kenya did little to counter the leaders' negative ICC rhetoric. ${ }^{199}$ The interviewee suggested that a combination of bribes and ad revenues led certain journalists to "shower[] Ruto with praise."200 Another interviewee a current or former ICC employee - shared the general sentiment that journalist reporting was influenced by favors and Kenyatta's control and manipulation of "a lot of the media.,"201

Kenyatta also used the anti-ICC, anti-West narrative to denigrate Raila Odinga, his political and ethnic opponent for the presidency. In late 2012, polling numbers showed that Odinga enjoyed "an apparently unbridgeable lead" over Kenyatta. ${ }^{202}$ The Jubilee Coalition, though, turned Odinga's support for the ICC process against him, claiming that Odinga was politically linked to the Court and backing the Court at the behest of his Western allies. ${ }^{203}$ The Jubilee Coalition highlighted that Odinga avoided ICC indictment, ${ }^{204}$ even though he had been Ruto's political ally in the 2007 elections. ${ }^{205}$ People Daily, a newspaper affiliated with Kenyatta, published a se-

Cheeseman, Gabrielle Lynch, \& Justin Willis, Democracy and its Discontents: Understanding Kenya's 2013 Elections, 8 J. OF E. AFR. STUD. 1, at 8 (2014) (referencing the campaign rhetoric painting Kenyatta and Ruto as victims of neo-colonialism).

197. See interview with Subject 333. See also Lynch, supra note 193, at 105 (describing the campaign rhetoric painting the Court as a neocolonial weapon of the West meant to punish Africa); Mueller, supra note 159, at 35 (describing the campaign rhetoric painting Kenyatta and Ruto as victims of Western imperialism).

198. Pheroze Nowrojee, The March 4 Polls and the ICC Case, Latest Kenyan News (Feb. 7, 2013), http://kenyauptodate.blogspot.nl/2013/02/the-march-4-polls-and-icccases.html [https://perma.cc/MP9U-SFYE].

199. Interview with Subject 568.

200. Id.

201. Interview with Subject 104.

202. Wolf, supra note 193, at 146. See also Erich Follath, 'Big Mama' and the Massacre: The ICC's Reputation in Kenya, SpIEgel Online (July 26, 2013), http://www.spiegel.de/international/world/reputation-of-icc-on-the-line-in-case-againstkenya-president-kenyatta-a-913090.html [https://perma.cc/F69K-5NKT] (stating that for much of the campaign, Odinga held a solid lead over Kenyatta).

203. See Lynch, supra note 193, at 106-107; Wolf, supra note 193, at 146.

204. See Lynch, supra note 193, at 105.

205. See Mueller, supra note 159, at 35. 
ries of articles suggesting that Odinga, not Kenyatta, should be criminally liable for the post-election crisis. ${ }^{206}$ Additionally, the Jubilee Coalition stoked a "three Os" conspiracy theory, emphasizing an alleged but unsubstantiated connection between Odinga, U.S. President Barack Obama, ${ }^{207}$ and the ICC Prosecutor Luis Moreno-Ocampo. ${ }^{208}$ Unlike Odinga, Kenyatta would defend Kenya's sovereignty and independence against the patronizing and colonialist West. ${ }^{209}$

ICC Prosecutor Ocampo featured in the anti-ICC narrative in another way: he became the embodiment of the colonialist West. One interviewee stated that Kenyans viewed ICC Prosecutor Ocampo as "too strident." 210 That interviewee suggested that Kenyans might have likened Ocampo, who hails from Argentina, to the "cowboylike" white colonialists of Kenya's past. ${ }^{211}$ Several interviewees expressed concern that a similar anti-ICC narrative could be employed in the future, across post-colonial Africa.

Through this colonialism frame, any foreign comment denouncing Kenyatta and Ruto proved their point. In 2012, British Foreign Minister William Hague stated that Kenya's international reputation would suffer if Kenyans elected Kenyatta and Ruto as their leaders. ${ }^{212}$ Members of Parliament allied with Kenyatta and Ruto were quick to denounce the remarks as evidence of Western imperialism and as confirmation that "the charges against the four Kenyans at the ICC are being used for strategic interests." ${ }^{213}$ In 2013,

206. Tome Francis Simiyu, Media Ownership and Framing in Kenya: A Study of the ICC Case Against Uhuru Kenyatta (2013), http://www.open-science-repository.com/mediaownership-and-framing-in-kenya-study-of-the-icc-case-against-uhuru-kenyatta.html [https://perma.cc/F639-RJJN] (finding that People Daily published pieces implicating Odinga's criminal liability more than twice as frequently as the Nation and Standard newspapers, which are not affiliated with either Kenyatta or Ruto).

207. To whom Odinga claimed to be biologically related. Odinga Says Obama Is His Cousin, BBC (Jan. 8, 2008), http://news.bbc.co.uk/2/hi/africa/7176683.stm [https://perma.cc/88FY-DEMC].

208. See Lynch, supra note 193, at 106. See also Interview with Subject 582 (stating that Kenyatta and Ruto successfully framed Odinga as the "voice of the international [foreign] community").

209. Lynch, supra note 193, at 106; see also T.F. Simiyu, supra note 206, Media Ownership (finding that People Daily, more so than the Nation and Standard newspapers, described Kenyatta as indomitable, or "capable of putting up a spirited fight").

210. Interview with Subject 338.

211. Id.

212. Simon Ndonga, Uhuru, Ruto allies critisise UK's Hague, CAPITAL NEws (Feb. 4, 2012), http://www.capitalfm.co.ke/news/2012/02/uhuru-ruto-allies-critisise-uks-hague/ [https://perma.cc/L7YH-MK76].

213. Id. 
U.S. Assistant Secretary of State for African Affairs Johnnie Carson said, "[T]he choice of who will lead Kenya is up to the Kenyan people, but it is also important to note that choices have consequences." 214 The French Ambassador echoed the point and stated that France would be reluctant to communicate with "people who are indicted by the ICC." 215

These statements provided grist for the Jubilee mill. ${ }^{216}$ After the statements by Western officials, Kenyatta's campaign questioned whether Kenyans "should allow foreign powers to dictate to them their choice of national leaders." "17 One person close to the Jubilee campaign called Carson's statement "[a] Godsend," since it showed foreign powers trying to dictate Kenya's affairs and also made Odinga look "like a project of western powers." 218 A person working on the Jubilee campaign said that Western governments' statements "had the effect of whipping up nationalism." 219

\section{ii. Leaders' Communication Advantage at Work}

Kenyatta and Ruto's anti-ICC rhetoric evidently resonated with the public, ${ }^{220}$ which otherwise had little first-hand knowledge or experience with the ICC. Their ticket, itself an ethnic compromise, manufactured a common Western enemy. It united rival ethnic

214. Uproar in Kenya over Johnnie Carson's statement on Elections, JANAK
COMMUNICATIONS http://janakcommunicationsupdates.blogspot.com/2013/02/uproar-in-kenya-over-us-johnniecarsons.html [https://perma.cc/4V6J-QFH8].

215. See Steven Brown \& Rosalind Raddatz, Dire Consequences or Empty Threats? Western Pressure for Peace, Justice and Democracy in Kenya, 8 J. OF E. AFr. STUD. 43, 5152 (2014).

216. Id. at 52. See also Interview with Subject 333.

217. Follath, supra note 202.

218. Machua Koinange, When International Criminal Court, Land Cases Became a Major Headache for President Uhuru Kenyatta and William Ruto, STANDARD (May 26, 2013), https://www.standardmedia.co.ke/article/2000084476/when-international-criminal-courtland-cases-became-a-major-headache-for-president-uhuru-kenyatta-and-william-ruto [https://perma.cc/DE2X-J2UY].

219. Id.

220. Interview with Subject 724 (referring to the ICC as "a big monster" that the Kenyan people united against to elect Kenyatta and Ruto). See also Brown \& Raddatz, supra note 215, at 52 (stating that Carson's statement that was echoed by others may have driven "many undecided Kenyans to the polls to rally behind Kenyatta or increased voter turnout among Jubilee's ethnic constituencies). 
groups $^{221}$ that five years earlier had been "butchering" one another. ${ }^{222}$ For the first time in Kenyan history, the majority of ethnic Kalenjins voted for an ethnic Kikuyu - Kenyatta - for the presidency. ${ }^{223}$ One Jubilee supporter, a veteran of four violent, ethnically polarized elections, captured the public us-versus-them sentiment well: "It's wrong for anyone to come from outside, even if they are seeking truth. It's Kenyans who should judge which way it should go. In your home, can anyone else come and determine your issues? All these decisions should be left to Kenyan citizens."224

In light of Kenya's history of "colonialism and the often hypocritical, patronizing, and unhelpful interventions of external actors, "225 it is unsurprising that anti-ICC, anti-West rhetoric resonated with the public. ${ }^{226}$ Groups that have been victimized in the past often preserve suffering in their collective memory, such that "victimhood becomes a prism through which society processes information and makes decisions." 227 A sense of collective victimhood results from traumatic experiences, including past colonial occupation," inflicted wars, prolonged discrimination and exploitation, and genocide. ${ }^{228}$ Collective victimhood heightens a group's need for solidarity and promotes the sense that the group must protect itself from foreign rivals. $^{229}$ African leaders have successfully used references to past racism and colonialism to rally their citizenry. ${ }^{230}$ When politicians bring

221. See Lynch, supra note 193, at 97 . As Lynch points out, the Kikuyus are Kenya's largest ethnic group with $17 \%$ of the population, while the Kalenjin constitute about $14 \%$ of the populace. $I d$. at 95 .

222. See Is the "MIGHTY" Uhuru Propaganda machine finally CRUMBLING?, KENYA TODAY (Nov. 15, 2014), https://www.kenya-today.com/news/uhuru-propaganda-machinefinally-crumbling-odm-moles-infritrating-statehouse, [https://perma.cc/7CF9-XT2L].

223. See Wolf, supra note 193, at 171 (quoting Kenyatta's speech in April 2013); Lynch, supra note 193, at 97-100 (reporting that the majority of Kalenjin and Kikuyu in the Rift Valley voted for Kenyatta in 2013).

224. David Smith, Kenyatta Bids for Kenyan Presidency Despite ICC 'Crimes Against Humanity,' GUARDIAN (March 3, 2013), https://www.theguardian.com/world /2013/mar/03/kenyatta-kenya-election-2013 [https://perma.cc/7YB8-8TN2].

225. Lynch, supra note 193, at 106.

226. Id.

227. See Daniel Bar-Tal, Lily Chernyak-Hai, Noa Schori, \& Ayeltet Gundar, A Sense of Self-Perceived Collective Victimhood in Intractable Conflicts, 91 INT'L REV. OF THE RED CROSs 229, 235-6 (2009).

228. Id. at 237.

229. Id. at 245 .

230. See James Hall, Continental Overview: African Leaders vs. The International Criminal Court, AFR. Conflict MonTHLy Monitor 6 (Dec. 2013). 
these shared experiences to the forefront, they set the stage for citizens to use their feelings of victimization to "explain away [an] indictment as the result of foreign intrusion or institutional bias."

Kenyatta and Ruto seized upon Kenyan collective memory and cultural identity to whip up resentment within their in-group against the out-group ICC. ${ }^{232}$ Indeed, Kenyatta was particularly well-suited to tap into Kenyans' resentment and fear of colonialism. His father, Jomo Kenyatta, had led the Kenya African Union, a key organization in the Kenyan independence movement. In 1952, the British colonial government arrested Jomo Kenyatta in an attempt to stall the independence movement and quell civil unrest. African nationalists across the continent called for his release. After Kenya won its independence in 1961, Jomo Kenyatta was elected Kenya's first Prime Minister and was subsequently elected its first President. $^{233}$ Uhuru Kenyatta, like his father before him and as his name suggests, ${ }^{234}$ would take on colonialist forces, win, and ascend to the Presidency. So the narrative went. ${ }^{235}$

231. Chaudoin \& Chapman, supra note 70, at 10. Scholars, studying attitudes towards the ICTY, have found that ethnic Serbs' reported distrust of the ICTY is based on biased reasoning resulting from entrenched nationalistic narratives that paint the in-group as the victim of the ill-intentioned out-group. See Milanovic, supra note 111, at 37-44 (referencing both Serb and Croat attitudes towards the ICTY); Ford, supra note 19, at 414-18 (arguing that the reason that most Serbs surveyed stated the ICTY was biased is because the tribunal's judgments ran counter to the dominant ethnic narrative painting Serbs as victims of, inter alia, neo-colonialism).

232. See Bar-Tal et al., supra note 227, at 247 (stating that "[p]oliticians often use collective victimization as a source of political power, and reminders of past and present victimization are a potent theme for recruitment and mobilization."); Milanovic, supra note 111, at 1-3 (referencing the "continued strength of ethnic nationalist narratives" to explain survey findings showing that most ethnic Serbs do not believe that the findings in the ICTY judgments concluding that Serbs committed mass atrocities are true); Cheeseman, Lynch, \& Willis, supra note 196, at 8 (noting that in the 1990s long-time Kenyan president Daniel arap Moi "expended much energy on repeated denunciations of Western interference").

233. Mwangi S. Kimenyi, Kenya's Elections: Implications of Ethnic Rivalries and International Intervention, BROOKINGS INSTITUTE (Feb. 12, 2013), https://www.brookings.edu/opinions/kenyas-elections-implications-of-ethnic-rivalries-andinternational-intervention/ [https://perma.cc/2WKV-55KQ]. According to Kimenyi, some commentators compared the stance of Western countries during the 2013 presidential elections in Kenya to the treatment of Jomo Kenyatta during the anti-colonialist rebellion.

234. "Uhuru" means "freedom" in Swahili.

235. This was a clear implication of Kenyatta's inauguration speech, which made extensive reference to Kenya's colonial past and Kenyatta's commitment to defying neocolonialist forces. FIFTH Estate BlOG (April 9, 2013), https://www.capitalfm.co.ke/eblog /2013/04/09/president-kenyattas-inauguration-speech/ [https://perma.cc/PM2A-DR8U] ("I acknowledge and pay tribute to the memory of my father, the late founding father of our na- 
Kenyatta and Ruto were successful in creating an anti-ICC narrative, which persuaded members of the public to vote across deeply-entrenched ethnic lines ${ }^{236}$ and to ignore the allegations that Kenyatta and Ruto had committed crimes against humanity. Their success, however, speaks to the communication advantage held by domestic leaders rather than any established ICC bias. Though the ICC has addressed nine African situations, six of these situations were self-referred ${ }^{237}$ or were referred by the Security Council with no dissenting votes from African States. ${ }^{238}$ Moreover, the ICC is currently investigating a Georgian situation and is preliminarily examining alleged crimes committed in Europe, Asia, and Latin America. ${ }^{239}$

Archbishop Desmond Tutu has argued that "the number of Africans put on trial is an indictment of leadership and democracy in some African countries, not of the court." ${ }^{, 40}$ Relatedly, ICC Prosecutor Fatou Bensouda has argued that critics of the ICC's caseload must consider that the Court, when it hears a case, strives to secure justice

tion, Mzee Jomo Kenyatta. May he and his fellow architects of liberation in Kenya and Africa as a whole rest in peace with the knowledge that this generation is committed to fulfilling their dreams of for our nation ... The breakaway from colonialism has not been easy [but] The great renaissance spoken of a mere 20 years ago is upon us.").

236. As suggested above, for Kenyatta to win the presidency, he needed the support of a substantial number of Kalenjin voters. This meant that Kalenjins would be voting for the Kikuyu leader who allegedly orchestrated violence against them following the 2007 presidential elections. Even if Kalenjins voters did not believe that Kenyatta was behind the postelection violence, a majority of Kalenjin voters had never thrown their support behind a Kikuyu candidate before. See supra note 235.

237. Ahmed Hassanein, Self-Referral of Situations to the International Criminal Court: Complementarity in Practice - Complementarity in Crisis, 17 INT'L CRIM. L. REV. 107, 10809 (2017) (listing Uganda, the Democratic Republic of the Congo, the Central African Republic - self-referred twice, Cote D'Ivoire, and Mali).

238. Id. (listing Sudan and Libya).

239. Preliminary Examinations, International Criminal Court, https://www.icccpi.int/Pages/Preliminary-Examinations.aspx [https://perma.cc/7JPS-AZS5]; Julius Barigaba, ICC Is not Targeting Africa, It Is Responding to Calls from Africa, EAST AFRICAN (Mar. 21, 2015), http://www.theeastafrican.co.ke/news/ICC-is-not-targeting-Africa-it-isresponding-to-African-calls/-/2558/2661408/-/tgy33y/-/index.html [https://perma.cc/8CHX2GAA]. Recent empirical work also suggests that claims of anti-Africa bias are, at best, "exaggerated" and that the ICC Prosecutor has focused the "gravest situations" for which the Court has jurisdiction. See generally Alette Smeulers, Maartje Weerdesteijn, \& Barbora Hola, The Selection of Situations by the ICC: An Empirically Based Evaluation of the OTP's Performance, 15 INT'L CRIM. L. REV. 1, 1, 38 (2015).

240. Desmond Tutu, Don't Let Leaders Get Away with Murder, STAR (Oct. 11, 2013), http://www.iol.co.za/the-star/don't-let-leaders-get-away-with-murder-1590432 [https://perma.cc/FP7B-3MET]. 
for African victims of State abuse or failure. ${ }^{241}$ Recent empirical work also suggests that the ICC Prosecutor has acted impartially and focused on the "gravest situations" for which the Court has jurisdiction. $^{242}$

A great deal of evidence shows that the ICC functions fairly and without a clear institutional bias against Africa or Kenya, in particular. $^{243}$ For Kenyatta and Ruto, however, the anti-ICC, anti-West narrative became a clever and convenient mechanism for deflecting attention away from their involvement in the post-election crisis. Their rhetoric, which inaccurately but effectively cast doubt on the objective legitimacy of the ICC, rendered them unassailable by Western States, civil society organizations with foreign ties, and certainly the remotely-located, foreign ICC.

\section{Distrust of Domestic Legal Institutions}

The public's trust in its own legal institutions defines, as a baseline, the public's trust in international legal institutions. Though an international court, or its adversaries, can shift public trust through targeted messaging, outreach efforts cannot affect, nor are they meant to affect, that baseline.

Kenyans had ample reason to distrust their judicial institutions. The Worldwide Governance Indicators Database shows that between 1996 and 2013, Kenya had weak rule of law and high levels of corruption relative to other States. A report by Philip Alston, then Special Rapporteur on Extrajudicial, Summary or Arbitrary Executions, referred to the Kenyan criminal justice system as "terrible."244 Each element of the criminal justice system, from investigation to judicial proceedings, was described as "slow and corrupt," giving rise to "impunity for criminals (particularly for those with power and money)." 245 A Human Rights Watch report referred to Kenya's

241. Esther Addley, Fatou Bensouda: The Woman Who Hunts Tyrants, GuARDIAn (June 5, 2016), https://www.theguardian.com/law/2016/jun/05/fatou-bensouda-internationalcriminal-court-tyrants [https://perma.cc/D96K-BBQZ] (quoting Bensouda as stating "If certain people are looking to shield the alleged perpetrators of those crimes, of course they will say we are targeting [African nations]. But ... the victims deserve justice, the victims are Africans, and in the absence of the ICC nobody else is giving them justice").

242. See generally Smeulers, supra note 239.

243. Id.

244. Philip Alston, Human Rights Council, Report of the Special Rapporteur on Extrajudicial, Summary or Arbitrary Executions, Mission to Kenya, May 26, 2009, at para. 23, 16-17.

245. Id. 
"decades of impunity" for political violence, noting that investigations into elections-related clashes were either suppressed or ignored if they reflected poorly on government officials. ${ }^{246}$ Not once did the Kenyan government prosecute, let alone convict, a high-level government official for inciting or engaging in political violence. ${ }^{247}$

Kenyans were, in fact, distrustful of their courts. According to an Afrobarometer ${ }^{248}$ survey conducted in 2014 , only nineteen percent of Kenyan respondents trusted their national courts "a lot," while thirty eight percent trusted courts "somewhat." Another thirty eight percent of respondents trusted their courts "just a little" or "not at all."249 Stunningly, sixty six percent of respondents believed Kenyan courts "always" or "often" treated people unequally. While eighty six percent of respondents said that ordinary citizens "rarely" or "never" get away with breaking the law, only twenty percent of respondents said the same about public officials. ${ }^{250}$

Several interviewees expressed doubts about the fairness of Kenya's courts. One interviewee stated that "there is no record of justice in Kenya.",251 According to the interviewee, "even so-called political assassinations are not prosecuted. Instead, the government creates a commission that takes the attention away from the matter; then the committee gets disbanded; then there is some commission report; then everything is dropped." ${ }^{252}$ Another interviewee said that "never in Kenya has a public servant been found guilty or spent time in a jail cell." The interviewee intimated that public servants can in-

246. Human Rights Watch, Ballots to Bullets: Organized Political Violence and Kenya's Crisis of Governance (March 17, 2008), Vol. 20, No. 1(A), at 17.

247. Stephen Brown \& Chandra Lekha Sriram, The Big Fish Won't Fry Themselves: Criminal Accountability for Post-Election Violence in Kenya, 11 AFR. AFFS. 244, 249 (2012).

248. Afrobarometer is a pan-African, non-partisan research network that conducts public attitude surveys in various African countries. See See AfrobArometer, Afrobarometer.org [https://perma.cc/A3K5-6EC9].

249. Afrobarometer, Summary of Results Afrobarometer Round Six Survey in Kenya 2014, 32 (2014), Compiled by: Institute for Development Studies (IDS) 32 (Question 52J), http://afrobarometer.org/sites/default/files/publications/Summary\%20of\%20results/ken_r6_s or_en.pdf [https://perma.cc/A96T-ZPVV].

250. See Rorisang Lekalake \& Stephen Buchanan-Clarke, Support for the International Criminal Court in Africa: Evidence from Kenya, Afrobarometer Policy Paper 1, 3 (2015), http://afrobarometer.org/sites/default/files/publications/Policy\%20papers/ab_r6_policypaper no23_kenya_anti_corruption.pdf [https://perma.cc/3V8A-UDAT]. The findings reported in the policy paper were based on interviews with 2400 adult Kenyans between November and December 2014. Id. at 2.

251. See Interview with Subject 417. See also Interview with Subject 333 (stating that it seems like the State is not interested in justice).

252. Id 
fluence Kenyan judges and magistrates to get their cases dismissed. ${ }^{253}$

Kenyans' dismissiveness of their domestic legal institutions affected the ability of victims of the post-election violence to secure justice and accountability. In February 2008, the Kenyan government established the Waki Commission, which was chaired by a Kenyan judge. The Waki Commission investigated the post-election violence, producing a 529-page report from which potential perpetrators' names were withheld. ${ }^{254}$ After the Kenyan government repeatedly failed to create a special tribunal to try potential perpetrators, the Waki Commission forwarded specific non-public information to the ICC Prosecutor. ${ }^{255}$ Shortly thereafter, the ICC Prosecutor opened the proprio motu investigation that would lead to charges against six suspects, including Kenyatta and Ruto. Despite the Waki Commission's early involvement in the ICC's Kenya investigation, the public harbored doubts about the accuracy and impartiality of the charges before the Court.

One survey, conducted by the Author and colleagues in 2015, found that roughly twice as many Jubilee voters believed that the ICC was biased against Africa than believed otherwise. ${ }^{256}$ Within the broader sample, $34.3 \%$ of respondents believed that the ICC was biased against Africa and $19.5 \%$ said they were neutral or unsure-but did not disagree that the institution might be biased. ${ }^{257}$ This, of course, says little about Kenyans' preconceptions about the fairness of process afforded the ICC's suspects, the efficiency of Court proceedings, or potential corruption of the ICC Prosecutor and judges. An individual who does not believe the ICC is biased against Africa may, and likely would, still impute the negative attributes of the

253. See Interview with Subject 568.

254. See WAKI COMMISSION REPORT, COMMISSION OF INQUIRY INTO THE POST ELECTION VIOLENCE (CIPEV) $347 \quad$ (2008), http://www.kenyalaw.org/Downloads/Reports/ Commission_of_Inquiry_into_Post_Election_Violence.pdf [https://perma.cc/R2NX-HXA8].

255. ICC Press Release, ICC Prosecutor Receives Sealed Envelope from Kofi Annan on Post-Election Violence in Kenya (July 9, 2009), https://www.icccpi.int/Pages/item.aspx?name=pr436 [https://perma.cc/JP9P-P923]; ICC Press Release, ICC Prosecutor Receives Materials on Post-Election Violence in Kenya (July 15, 2009), https://www.icc-cpi.int/Pages/item.aspx?name=pr438 [https://perma.cc/XMZ3-ZSFB].

256. Five hundred and seven Kenyans from five separate regions of Kenya were selected at random for the survey. Tessa Alleblas et al. Is the International Criminal Court Biased Against Africans? Kenyan Victims Don't Think So, WASH POST (March 6, 2017), https://www.washingtonpost.com/news/monkey-cage/wp/2017/03/06/is-the-internationalcriminal-court-biased-against-africans-kenyan-victims-dont-thinkso/?utm_term=.ee9f6b1b0d8b [https://perma.cc/V89U-R9N7].

257. Id. 
Kenyan criminal justice system to the ICC.

\section{CONCLUSION}

The ICC should not be forced to rely on self-referrals and to pursue only those perpetrators a State's leaders are willing to sacrifice. The Court must be able to intervene over the objection of States whose leaders refuse to bring perpetrators of mass atrocities to justice. The international community owes that much to victims.

Ideally, the Assembly of States Parties and Security Council will take affirmative action to induce, if not coerce, compliance with Court arrest warrants and requests. Third-States will remind situation States that the Rome Statute obligates States Parties to cooperate with investigations and permit ICC personnel to travel safely within their borders - at least for the purposes of engaging with witnesses and victims. They will employ diplomatic measures to encourage situation States to comply. Alas, the ICC's top-down compliance mechanisms have been thus far illusory and likely will continue to be so. In 2013, the African Union "decided" that no international tribunal should be permitted to try the leader of any Member State and that the ICC should suspend its cases against Kenyatta and Ruto. ${ }^{258}$ One interviewee for this Article lamented that "the Kenya cases were not really a priority for other States Parties or for the US. In other words, the ICC was not getting a lot of help from other states in terms of forcing Kenya to cooperate with the ICC." 259

Unless the Assembly of States Parties or the Security Council takes decisive steps in response to the Court's future findings of State noncompliance, the ICC will have to rely on bottom-up compliance. For the ICC to succeed in its goal of bringing justice to victims of mass atrocities, the ICC and the international community must work together to find ways to enhance and protect the ICC's domestic perception legitimacy. Kenya is not the only State in which anti-ICC rhetoric could be deployed. For the same reasons that Kenyatta and

258. ICC Press Release, supra note 255; ICC Press Release, ICC Prosecutor Receives Materials on Post-Election Violence in Kenya (July 15, 2009), https://www.icccpi.int/Pages/item.aspx?name=pr438 [https://perma.cc/XMZ3-ZSFB].

259. See Interview with Subject 102. Brown and Raddatz make a similar point about the world's waning support for the Kenya cases. They note that although some Western leaders threatened consequences if Kenyatta and Ruto took office, follow-through seemed lacking. They explain that Western countries initially snubbed Kenyatta by not congratulating him on becoming president. Afterwards, it was "business as usual," with governments' issuing cryptic warnings about cooperating with the ICC, but not implementing any sanctions, such as withdrawing aid. Brown \& Raddatz, supra note 215, at 52-53. 
Ruto's rhetoric resonated with Kenyans, similar rhetoric could resonate in other post-colonial States with weak domestic legal institutions.

How can the ICC avoid the same fate it suffered in the Kenya cases and achieve domestic perception legitimacy when it intervenes over a State's objection? The evidence from the Kenya case study convinces this Author that bridging the legitimacy divide in such cases will require funding, ICC prioritization of in-person outreach, engagement from civil society organizations, advancement of rule of law, and time.

First, the States Parties must provide the ICC with sufficient funding to allow ICC personnel to conduct in-person outreach with domestic audiences in situation States. Even if in-person outreach is costly, and the ICC has to retain a security staff, outreach is critical. The ICC must also prioritize conducting its own in-person outreach, at least when the ICC intervenes over a State's objection and civil society actors face a hostile environment. The Kenya case study is a lesson in what can happen when in-person engagement is lacking or minimal. Domestic leaders, because of their communication advantages in the situation State, can mobilize the public against the ICC if the ICC fails to raise awareness and understanding.

Second, civil society organizations must act as norm entrepreneurs in and around situation States; they must support compliance with the ICC and advance norms of international criminal justice and accountability. ${ }^{260}$ Civil society organizations, when permitted to operate, have similar communication advantages as have domestic leaders. Acting in-State, civil society organizations can host local events and build local coalitions. Moreover, they can take advantage of their shared national identity and cultural touchstones to message to the public. Though the Kenya case shows that civil society organizations will not always be able to function in situation States, their role in building the ICC's domestic perception legitimacy is not so geographically limited. It is important that civil society organizations target third-States, in addition to situation States, to create a critical mass and facilitate an ultimate "cascade" of support

260. Norms spread with the help of agents, often referred to as "norm entrepreneurs" or "transnational moral entrepreneurs," who use persuasion to convince a community to adopt the preferred behavior. See generally Martha Finnemore \& Kathryn Sikkink, International Norm Dynamics and Political Change,” 52 InT'L ORG. 887, 895-897 (1998) (explaining norm influence and norm entrepreneurs). See also Harold Koh, Why Do Nations Obey International Law?, 106 YALE L. J. 2599, 2656 (1997) (referring to the role of transnational moral entrepreneurs). 
for the ICC. ${ }^{261}$ Norms of compliance will spread more quickly if the ICC does not have to work alone.

Third, international actors must continue supporting global rule of law and domestic capacity-building initiatives. This is a task primarily for States, international political institutions rather than international judicial institutions, and civil society organizations. The ICC's much-lauded involvement in the Colombian peace process ${ }^{262}$ may suggest a role for the ICC in domestic capacity-building. ${ }^{263}$ That role would be limited, however, to the Court assisting States to prosecute atrocities in their domestic courts - which may have ancillary but lasting effects on rule of law.

Fourth and finally, all of this would take time. If the relevant actors commit to building the Court's domestic perception legitimacy, domestic audiences will eventually trust the ICC and adopt the norms of international criminal justice and accountability as their own. Someday the public, "[d] etermined to put an end to impunity" and "[r]esolved to guarantee lasting respect for and the enforcement of international justice," 264 will induce the compliance of situation States, even if the Assembly of States Parties and the Security Council will not.

261. A cascade presumably would result from a combination of top-down and bottomup compliance mechanisms, i.e. a combination of a State's international, strategic interests and its responsiveness to public mobilization. See, e.g., Finnemore and Sikkink, supra note 260 , at 895 .

262. Ainley, see supra note 16

263. This role has been referred to as "positive" or "proactive" complementarity. For an argument against positive complementarity, see Christine Bjork \& Juanita Goebertus, Complementarity in Action: The Role of Civil Society and the ICC in Rule of Law Strengthening in Kenya, 14 Yale Hum. RTS. \& Dev. J. 205, 213 (2014). For a view in favor, see generally William W. Burke-White, Proactive Complementarity: The International Criminal Court and National Courts in the Rome System of International Justice, 49 HARV. INT'L L.J. 53 (2008).

264. Rome Statute, supra note 1, Preamble. 